\title{
Article \\ Shrines and Pilgrimages in Poland as an Element of the "Geography" of Faith and Piety of the People of God in the Age of Vatican II (c. 1948-1998)
}

\author{
Franciszek Mróz (D)
}

check for updates

Citation: Mróz, Franciszek. 2021. Shrines and Pilgrimages in Poland as an Element of the "Geography" of Faith and Piety of the People of God in the Age of Vatican II (c. 1948-1998). Religions 12: 525. https://doi.org/ $10.3390 /$ rel12070525

Academic Editor: Salvador Ryan

Received: 19 May 2021

Accepted: 7 July 2021

Published: 13 July 2021

Publisher's Note: MDPI stays neutral with regard to jurisdictional claims in published maps and institutional affiliations.

Copyright: (C) 2021 by the author. Licensee MDPI, Basel, Switzerland. This article is an open access article distributed under the terms and conditions of the Creative Commons Attribution (CC BY) license (https:// creativecommons.org/licenses/by/ $4.0 /)$
Institute of Geography, Pedagogical University of Krakow, 30-084 Krakow, Poland; franciszek.mroz@up.krakow.pl

Abstract: This research is aimed at learning about the origins and functions of shrines, and changes to the pilgrimage movement in Poland during the Vatican II era (c. 1948-1998). The objective required finding and determining the following: (1) factors in the establishment of shrines in Poland during this time; (2) factors in the development of shrines with reference to the transformation of religious worship and to the influence of political factors in Poland; (3) changes in pilgrimage traditions in Poland, and (4) changes in the number of pilgrimages to selected shrines. These changes were determined by archive and library research. Additionally, field studies were performed at more than 300 shrines, including observations and in-depth interviews with custodians. Descriptive-analytical, dynamic-comparative and cartographic presentation methods were used to analyze results.

Keywords: pilgrimage; popular piety; sacred place; shrines; Vatican II

\section{Introduction}

Pilgrimages are some of the oldest and most permanent religious practices in all major religions around the world (Chélini and Branthomme 1982; Collins-Kreiner 2010; Timothy and Olsen 2006). Since the beginning of the history of mankind, pilgrimages to sacred sites have contributed to the development of the geographic and cultural-civilizational horizon of nations (Coleman and Eade 2004; Dyas 2020; Eliade 1969; Jackowski 2003; Mróz 2021b; Singh 2004). A renaissance in travel motivated by religion or religious and cognitive reasons has been observed worldwide since the late 20th century (Bowman et al. 2020; Digance 2003; Eade 1992; Margry 2008; Mróz 2019; Reader 2007).

Shrines and pilgrimages contain both static and dynamic geographic elements. They have their history and are subject to constant transformations (Cohen 1992; Kaszowski 1996; Krogmann 2007; Maddrell et al. 2014; Mróz 2021b; Robinson 1997; Timothy and Olsen 2006; Turner and Turner 1978). As part of the geographic space covered by pilgrims from the starting point of the pilgrimage to the sacred site and back, the pilgrimage space is unique and dynamic for each shrine and for each pilgrim (Kaszowski 1996; Mróz 2021a; Roszak 2017; Roszak and Tykarski 2020; Oviedo 2019; Ostrowski 2017). For pilgrims, a pilgrimage is also both a journey to a sacred place, and an inimitable process encompassing every experience occurring on the way to the destination (Ostrowski 2020; Roszak 2020).

Pilgrimages in Poland have a tradition of several centuries (Jackowski 2003). Currently, there are 800 shrines in Poland, 98\% of which are associated with the Catholic Church (Mróz 2021a). The Polish pilgrimage space is dynamic; it keeps evolving and transforming. It constitutes the centuries-old heritage of faith and folk piety of previous generations. The space comprises churches, convents of religious congregations, synagogues, mosques, churches of Priestless Old Believers, cemeteries, tens of roadside crosses, chapels, and especially sacred sites-shrines where miraculous or gracious images of Virgin Mary, images of the Lord (mainly crosses), and images of saints and beati are venerated, as well as ohels (tombs) of rabbis and tzadiks (for example: ohel of Reb Elimelech of Lizhensk in Leżajsk). 
A myriad of papers in Polish are devoted to Vatican II constitutions (Bartnik 1987; Świeżawski 1987) and to in-depth reflections on the authentic reception of Vatican II in the life and activity of the Church in Poland (Kobus 2006; Krukowski 1987; Mariański 1987; Półtorak 2006; Przygoda 2006; Stala 2006; Strzelczyk 2008). What is striking is the fact that none of the Council documents-neither the dogmatic constitutions nor the pastoral constitution-refer to pilgrimages, which are common forms of expression of popular devotion (Krzyżak 2014). Doburzyński (2021) points out the fact that this topic is not frequently mentioned in any official documents of the Church in any era. It was only the Code of Canon Law of 1983 that mentioned pilgrimages next to the definition of a "shrine" (Kodeks Prawa Kanonicznego (przekład polski zatwierdzony przez Konferencje Episkopatu) 1984). It was not until 25 April 1998 that a Church document analyzed pilgrimages, in The Pilgrimage in the Great Jubilee, published by the Pontifical Council for the Pastoral Care of Migrants and Itinerant People (www.migracja.episkopat.pl/wp-content/uploads/2016/1 2/Pielgrzymka-w-Wielkim-Jubileuszu.pdf (accessed on 1 July 2021).

It is surprising that the Fathers of the Second Vatican Council, also known as the Pastoral Council, made revolutionary changes in various spheres of the life of the Catholic Church, especially in teachings, liturgy and cult, and pastoral service (Półtorak 2006), but failed to focus on pilgrimages, which are a complex phenomenon full of meaning. However, when it comes to the Catholic Church in Poland, the huge importance of shrines to the history of the Polish nation was emphasized many times by the Primate of Poland, Cardinal Stefan Wyszyński, and by Cardinal Karol Wojtyła. Primate Wyszyński emphasized that shrines are "places where God wanted to put his divine feet on the ground, among people. Because He loves to be close to Sons of Man", (Wyszyński [1962] 2009, p. 306).

Shrines and pilgrimages in Poland during the Vatican II era have not been subject to in-depth synthetic research by historians, theologians, sociologists or geographers so far. The existing studies are primarily devoted to communist-era pilgrimages to selected shrines or groups of shrines, usually within the area of one diocese or region. This gap in research was one of the reasons why the author undertook this study on the transformation of pilgrimage space during the Vatican II era.

This research was aimed at finding out about the functioning of shrines and transformations in the pilgrimage movements in Poland during the Vatican II era (approx. 1948-1998). The objective required finding and determining: (1) factors in the establishment of shrines in Poland during this time, (2) factors in the development of shrines with reference to the transformation of religious worship and to the impact of political factors in Poland, (3) changes in pilgrimage traditions in Poland, and (4) changes in the number of pilgrimages to selected shrines.

The Vatican II era is a particularly significant period in the history of the Catholic Church in Poland, in the history of popular piety, and in the history of Polish pilgrimages and of the development of Polish shrines. The Second Vatican Council (1 October 1962-8 December 1965) occurred during the preparations for the celebrations of the millennium of Christianity in Poland (1966). Pilgrimages during the period from the 1960s until the 1989 transformation of the political system occurred to a massive extent in Poland, which had never been experienced before in the history of the Polish Catholic Church (Myszor 2008). A persistent increase in pilgrimages was noted at the national shrine of Poland in Jasna Góra and in tens of Marian shrines, shrines of Jesus Christ, and those of other saints and beati (those who are beatified). Coronations of images of Virgin are were immensely important to the "geography of faith" and "geography of pilgrimages" in Poland. With the consent of the Holy See, the Primate of Poland (Cardinal Stefan Wyszyński) and Cardinal Karol Wojtyła primarily celebrated these coronations. The appointment of the Metropolitan Bishop of Krakow, Cardinal Karol Wojtyła, as Pope (16 October 1978) and the establishment of the Independent Self-Governing Trade Union "Solidarity" (August 1980) were the breakthrough events in the 20th century history of both the Catholic Church and Poland. These two events made Poles aware of their national identity and sovereignty, which finally led to the collapse of the communist system in Poland (Mróz 2021a). 


\section{Results}

\subsection{Factors Affecting the Development of Pilgrimages and Shrines during the Vatican II Era}

The analysis of the origins and functioning of shrines, and the development of pilgrimages, in Poland during the Vatican II era requires taking into account an entire group of religious, geographic, historical, socio-economic, cultural and political factors (Figure 1). During the first months of the end of WWII and in subsequent years of the Vatican II era, the Polish pilgrimage space was considerably transformed and changed.

It should be emphasized that during the Vatican II era, the Polish Church struggled with completely different problems than those faced by Churches in Western European countries (Bartnik 1987). In the case of Poland, one of the key activities on which the philosophy and service of the Church were focused was care for the Catholic identity of the Polish nation, which was heavily restricted and attacked by communist authorities. At the time, the Church in Poland was an important space of freedom. Strzelczyk emphasizes that "the difference in contexts is of immense importance to the understanding of the entire reception of Vatican II in Poland", because "the main subject of the Council debates, from the theological perspective, was not in the centre of interests of the Polish Church", (Strzelczyk 2008, p. 47).

A key step in the preliminary research related to the functioning of sanctuaries and the development of pilgrimages in Poland during the Vatican II era was to take into account the historical context, the transformation of the social and political system in communist Poland, and changes to state borders in 1945. As decreed during the Yalta Conference, Poland lost $48 \%$ of its pre-war territory in the east.

Changes in pilgrimages and the network of pilgrimage centers in Poland during the Vatican II era comprise five main time intervals. Pilgrimages in Poland have been characterized by, first, a boom in pilgrimages to Polish shrines from 1945 to 1949, followed by a regression in pilgrimages during the period from 1950 to 1956 as a result of the anti-religion and anti-church policy of the communist authorities of the Polish People's Republic. The third stage witnessed a distinct increase in pilgrimages during the period from 1957 to 1978, which was mainly the result of preparations for and celebrations of the millennium of the Baptism of Poland and the Holy Year 1975 (the Great Novena before the Millennium of the Baptism of Poland, and processions featuring a replica of the image of Our Lady of Częstochowa to all parishes). Fourth, the intense development of pilgrimages occurred between 1979 and the transformation of the political system, economy and society in 1989, as a consequence of the pontificate of John Paul II, the Pope from Poland, and his pilgrimages to his homeland. Finally, 1990-1998 saw the distinct development of pilgrimages and religious tourism (1990-1998), as especially related to the pilgrimages of John Paul II to Poland, the development of the cult of Divine Mercy, and the beatification and canonization of Poles (Mróz 2014; Datko 2016).

The end of WWII and the regaining of independence by Poland in 1945 intensified pilgrimages to Polish shrines. However, the period did not last long, due to the anti-religious and anti-church policy of the communist authorities (Mróz 2021a). On 12 September 1945, the Council of Ministers of the Provisional Government of National Unity decreed that the concordat concluded in 1925 between the Republic of Poland and the Holy See no longer applied, as it had been unilaterally terminated by the Holy See (Włodarczyk 1974). 


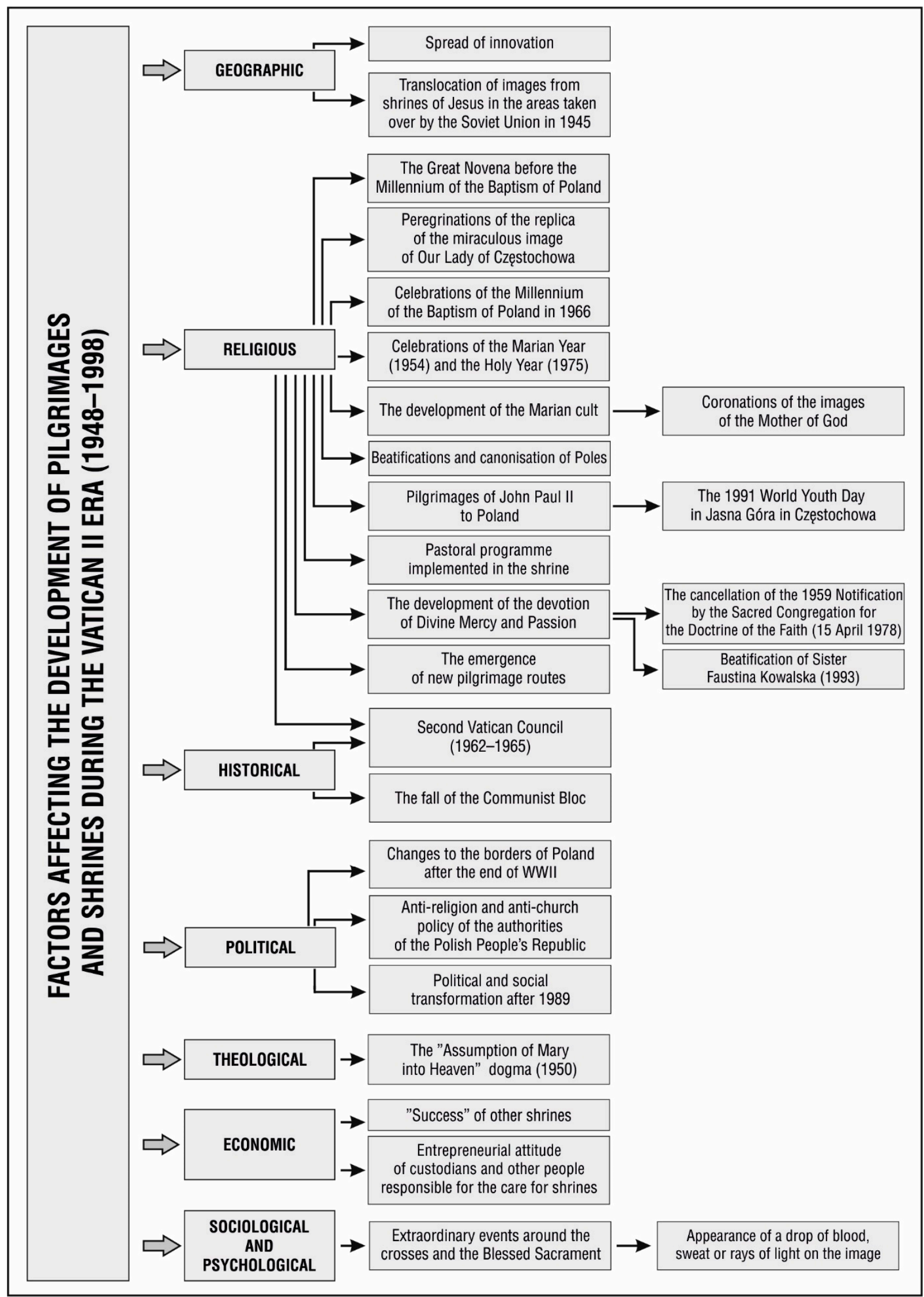

Figure 1. Factors affecting the development of pilgrimages and shrines during the Vatican II era (c. 1948-1998). Source: author. 
As a result of changes in territory, the Polish pilgrimage space began to include shrines that had not been situated within the borders of the Republic of Poland during the interwar period (e.g., Bardo Ślaskie, Gietrzwałd, Góra Świętej Anny, Krzeszów, Święta Lipka, Trzebnica, Wambierzyce) (Datko 2016). New pilgrimage centers associated with the cult of images brought from the eastern areas of the Republic of Poland and taken over by the Soviet Union in 1945 were also established. Priests and the faithful who were leaving their home towns in the areas of the former Republic of Poland risked persecution by Soviet communists when removing the miraculous images they had cherished in their parish churches for years (Kukiz 2000; Mróz 2021a; Skowron-Charif 2001; Sołjan 2002). The relocation of miraculous images of the Lord (more than 10 images), the Virgin Mary (approx. 140 images) and saints (more than 10 images) from sacred sites in the areas taken over by the Soviet Union in 1945 resulted in the emergence of more than 20 pilgrimage centers in Poland after 1945, mainly Marian loca sacra (Datko 2016; Kukiz 2000, 2002; Mróz 2021a). The change in the eastern border of Poland in 1945 had an immense impact on the reduction in pilgrimages to shrines located near the Polish-USSR border, such as Kalwaria Pacławska (Mróz 2021a).

The extensive research undertaken for this article, from archives and shrine custodian interviews, determined that in 1948 there were nearly 400 shrines and pilgrimage sites in Poland. Roman Catholic Church shrines constituted the major focus of pilgrimages during the post-war period. However, several Greek Catholic shrines (Grabarka and Jabłeczna) and pilgrimage sites of Muslims (Bohoniki and Kruszyniany) should also be mentioned here. During WWII, the Nazis murdered almost the entire Jewish community in Polish lands, and destroyed synagogues, cemeteries, and the ohele (Hebrew: tent) placed over the graves of Hassidic leaders, to which thousands of Hassids had been going on pilgrimages before the outbreak of the war. After 1945, the communist authorities of Poland closed devastated Jewish cemeteries and took steps to completely eliminate them (Gładyś and Górecki 2005). As regards Roman Catholic shrines, Marian shrines comprised the largest group, with more than 300 sites; 62 of these sites had images of the Mother of God crowned, based on specific papal consent for each location. In 1948 there were still 43 shrines in Poland devoted to Jesus Christ and the Holy Trinity, and 36 shrines of saints and beati. At the beginning of the Vatican II era, two regions in Poland were distinguished by a density of shrines: the Polish Carpathian Mountains (about 100 shrines) and the historic region of Wielkopolska (more than 70 shrines). At the time, the areas of western and northern Poland, or "Regained Territories" that were allocated to Poland after WWII in accordance with the arrangements made at the Potsdam Conference, were "blank spots" on the map of Polish shrines (Konopka and Konopka 2003) (Figure 2).

In 1949, the then authorities of the Polish People's Republic started to persecute the Catholic Church and impose restrictions on it. For example, the Department of Security arrested several hundred priests, while the Polish episcopate was accused of inspiring anti-state activity in the clergy. The regression in pilgrimages in Poland continued until the early 1960s, despite the fact that communists slightly softened their attitudes during the Khrushchev Thaw and the 1956 political transformation (Sołjan 2002). 


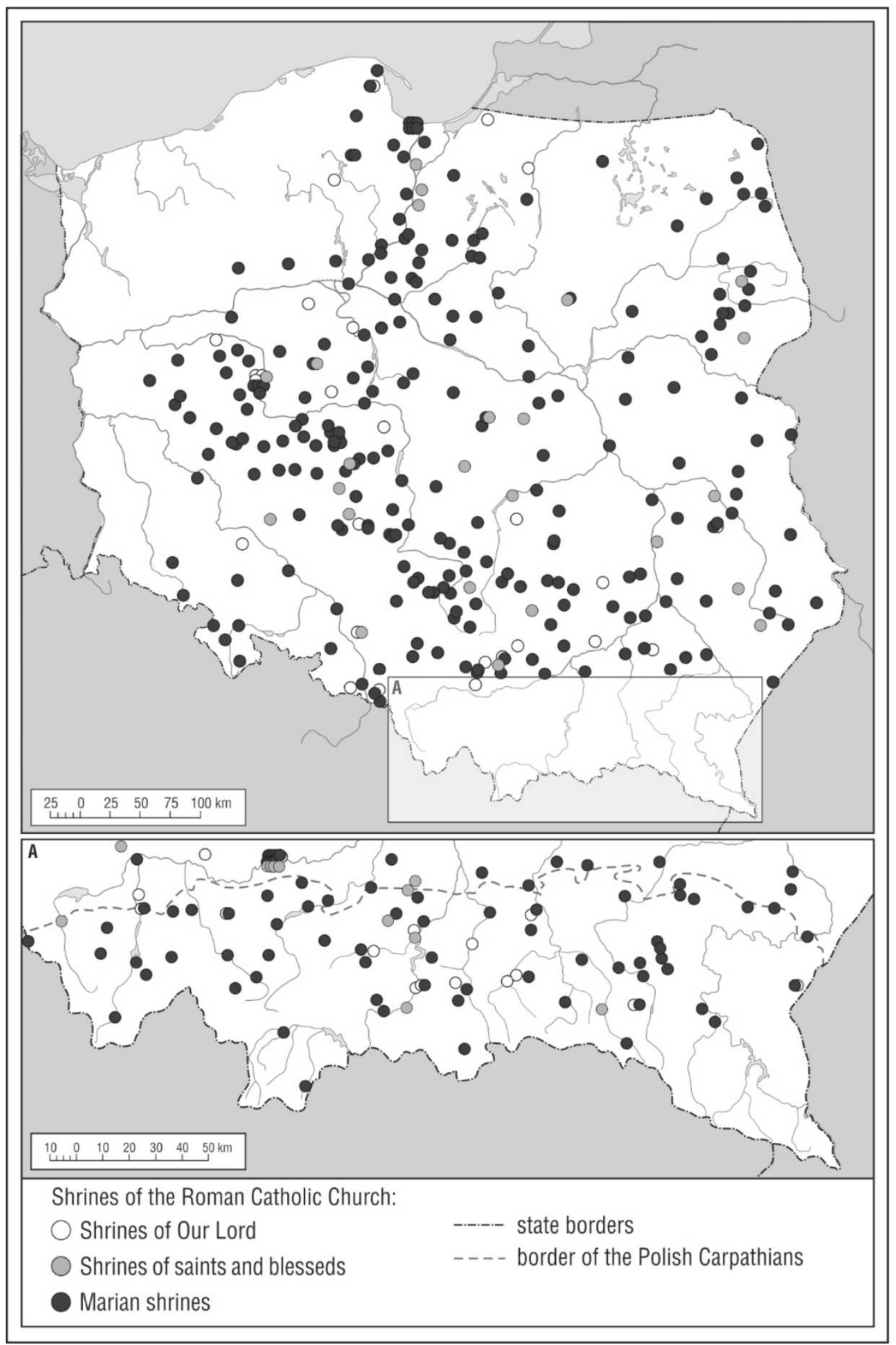

Figure 2. Shrines of the Catholic Church in Poland in 1948. Source: author.

\subsection{The Great Novena before the Millennium of the Baptism of Poland}

The late 1950s and the early 1960s marked a time of great reforms in the Catholic Church, initiated during the Second Vatican Council, which was opened on 11 October, 1962 by Pope John XXIII, and closed on 8 December 1965 by Pope Paul VI. During that time, the Catholic Church in Poland saw the implementation of the pastoral program, developed by Cardinal Stefan Wyszyński (1901-1981), the Primate of Poland, referred to by Poles as the "Primate of the Millennium" upon his death. Cardinal Wyszyński's maxim was "I bet it all on the Virgin Mary" (Okońska 2001a; Zieliński 2008). His relentless and uncompromising attitude to the attempted atheization of Poland by the communist 
authorities was vitally important to the development of the awareness in Polish Catholics of what was happening to their society.

Cardinal Wyszyński was arrested on 25 September 1953 because of his defense of the Christian identity of the nation and his firm opposition to the arrest of Bishop Czesław Kaczmarek in January 1951. He was subsequently interned without court judgment until 28 October 1956. While interned, Cardinal Wyszyński made an act of personal submission to the Virgin Mary: "Holy Mother, I submit to your captivity totally (...). The Mediatrix of all graces, everything I do with your Immaculate Hands will be entrusted to the grace of the Holy Trinity-Soli Deo!" (Okońska 2001b). Three years later, in August 1956, he undertook a nine-year program of religious and moral revival of Polish society-the Great Novena before the Millennium of the Baptism of Poland. The Novena was preceded by celebrations of great anniversaries in the subsequent three years - the Marian Year (1954) declared by Pope Pius XII on the hundredth anniversary of the Immaculate Conception dogma, the 300th anniversary of the victorious defense of Jasna Góra against the invasion of Swedish troops (1955), and the 300th anniversary of the Lviv Oath of King John II Casimir and the declaration of Mary as the Queen of Poland (1 April 1656 in Lviv) (Kupiszewska 2014).

On 26 August 1956, the Jasna Góra Vows of the Polish Nation took place in the shrine of Our Lady of Jasna Góra in Czesstochowa. The prayer, taking the form of an oath to the Virgin Mary, was read by Bishop Michał Klepacz (serving as president of the Polish episcopate) on behalf of the detained Cardinal Wyszyński. For the celebration, it is estimated that an astonishing one million people from around the country flocked to the small town. The empty chair of the primate was a symbol of calls to set Cardinal Wyszyński free.

The social turmoil in October 1956 led to transformation in the top ranks of the communist authorities, resulting in the rise of Władysław Gomułka to First Secretary of the Central Committee of the Polish United Workers' Party. Under social pressure, Gomułka made a considerable compromise with the Catholic Church in Poland and released Cardinal Stefan Wyszyński. However, the period of liberalization in church policy was short, and towards the end of 1958, communist authorities returned to repressive activities and harsh attacks on the Church, in particular the clergy. Communists removed crosses from school classrooms, prohibited religious education from schools, did not grant permits to construct new churches, returned to the military conscription of clergymen, and initiated a campaign to destroy sacred buildings. For example, many military chapels and garrison churches were demolished (Wysocki 2008).

In his speeches, Wiesław Gomułka, First Secretary of the Central Committee of the Polish United Workers' Party, continually insulted Primate Wyszyński and attacked the millennium program of the Catholic Church. The official inauguration of the Great Novena before the Millennium of the Baptism of Poland saw the participation of Primate Stefan Wyszyński on 3 May 1957 in Częstochowa. The nine-year program of the Great Novena included individual vows, including those to defend life, the Catholic family, marriage, faith, and social justice, as well as to venerate the Holy Mother.

The Shrine of Our Lady of Jasna Góra in Czestochowa, the national shrine of the Polish nation, was a center of key importance when the Great Novena program was implemented. It was also the site of the main celebrations of the Millennium of the Baptism of Poland in 1966, which were led by the Primate of Poland, Cardinal Stefan Wyszyński. The Polish episcopate invited Pope Paul VI to the event, but Gomułka did not agree to the visit, which became an international scandal. Again, an empty throne was the symbol of his absence. In 1966, approximately 2 million people visited the Shrine of Our Lady in Czesstochowa (Jabłoński 2000; Jackowski 2005).

Primate Stefan Wyszyński also included other shrines in Poland in the agenda of the Great Novena, which was to prepare Poles spiritually for the celebrations of the Millennium of the Baptism of Poland. For this purpose, a new department for Polish shrines was established as part of the Marian Committee with the Episcopate of Poland (Kupiszewska 2014). In his speech to the priests gathered in the shrine in Jasna Góra in 
1959, Cardinal Wyszyński emphasized the importance of shrines to the development of Polish piety: "Their immense network in all dioceses in Poland, three hundred sources of the grace of Jesus spreading from Mary throughout the whole Country. This is the power! And this power should be used in the work of moral renewal of the Nation, especially when working on the Great Novena before the Millennium", (Wyszyński 2006, p. 234). Primate Wyszyński gave the custodians of shrines a duty to perform during the third year of the Great Novena: "to animate all Marian sources of grace during the Year of Life, to animate all Marian shrines, even the smallest, most 'extinct' ones", (Wyszyński 2006, p. 235).

Earlier, while interned, Primate Wyszyński had developed an idea for the pilgrimage of a replica of the miraculous image of Our Lady of Czesstochowa to all parishes around Poland. The replica of the image was consecrated by Pope Pius XII in the Vatican on 14 May 1957. The peregrination of the image started on 29 August 1957 at the Warsaw Archsee (Okońska 2008). Communist authorities tried to "arrest" the replica of the image of Our Lady of Jasna Góra at least twice (in Liksajny and in Lublin). In September 1966, when the replica of the image was being transported from Warsaw to Katowice, the Security Service ordered that the image be transported to Jasna Góra instead. The processions continued until 1972, with empty frames of the image accompanied by a sign with the words "detained and confined in Jasna Góra." At the time, the militia and officers of the Security Service checked each vehicle leaving the shrine of Jasna Góra to see if the replica of the miraculous image of Our Lady of Jasna Góra was being transported (Okońska 2008; Żaryn 2008).

\subsection{The Development of Marian Shrines}

Primate Wyszyński believed that Marian shrines played a very important role in the development of Marian piety. With reference to such shrines, he wrote that "even the small and poor ones are like the hand of Immaculate Mary, the Queen of Poland, reached out to help the nation and defend it", (Królowa Polski w wielu obliczach (Królowa Polski w wielu obliczach: 7). Shrines promoted mass religion, and initiated and supported religious celebrations, which gathered tens of thousands of followers (Datko 2016). Such celebrations mainly included coronations of miraculous Marian images. Coronation celebrations, which were mainly presided over by Primate Wyszyński, strengthened the Poles spiritually in their national, social and personal dedication to Mary, the Mother of the Church and the Queen of Poland.

It should be recalled here that the custom of crowning the gracious and miraculous images of the Mother of God has had a long history in the religious life of Poles. The first image of the Mother of God in Poland, the miraculous icon of Virgin Mary in the Church of the Pauline Fathers in Jasna Góra, was crowned in 1717 with the consent of the Holy See. Before the late 18th century, 29 images of the Mother of God had been ceremonially crowned in Poland; during the period of the partitions of Poland, 12 images were crowned (1800-1918), and during the period of the Second Commonwealth of Poland (1919-1939), 22 images were (Fridrich 1904; Mróz and Mróz 2012; Witkowska 1996).

From the end of WWII until 1961, only two celebrations associated with the crowning of images of the Mother of God were held: in in village Piotrkowice (Świętokrzyskie Voivodeship) and in the parish church in Poznan. In the course of preparations for the celebration of the Millennium of the Baptism of Poland, bishops designated at least one image of the Mother of God in each of the dioceses in Poland (Sołjan 2002). During the period of the Great Novena before the Millennium of the Baptism of Poland (1957-1965), twelve coronations based on papal consent ("in the name of and with the authority of God") were held with the appropriate consent of the Congregation of Divine Worship. During the Year of the Millennium of the Baptism of Poland (1966), nine images of the Mother of God were crowned (during Millennium celebrations in Jasna Góra on 3 May 1966, Primate Wyszyński crowned the image of Our Lady of Jasna Góra again). In subsequent years (1967-1970), there were 20 coronations (cf. Grażyna od Wszechpośrednictwa and Szymczak 
1999; Witkowska 1996). It should be emphasized, with reference to the Vatican II, era that the number of coronations of papal images of the Virgin Mary in Poland from 1948 to 1998 (126 coronations) was a rare phenomenon around the world (cf. Jackowski et al. 1999) (Figure 3). During that period, the Primate of Poland, Cardinal Stefan Wyszyński, celebrated the greatest number of coronations out of all bishops of the Catholic Church: a total of 41 coronations and six re-coronations of Marian images (Kupiszewska 2014; Datko 2016) (Figures 4-8).

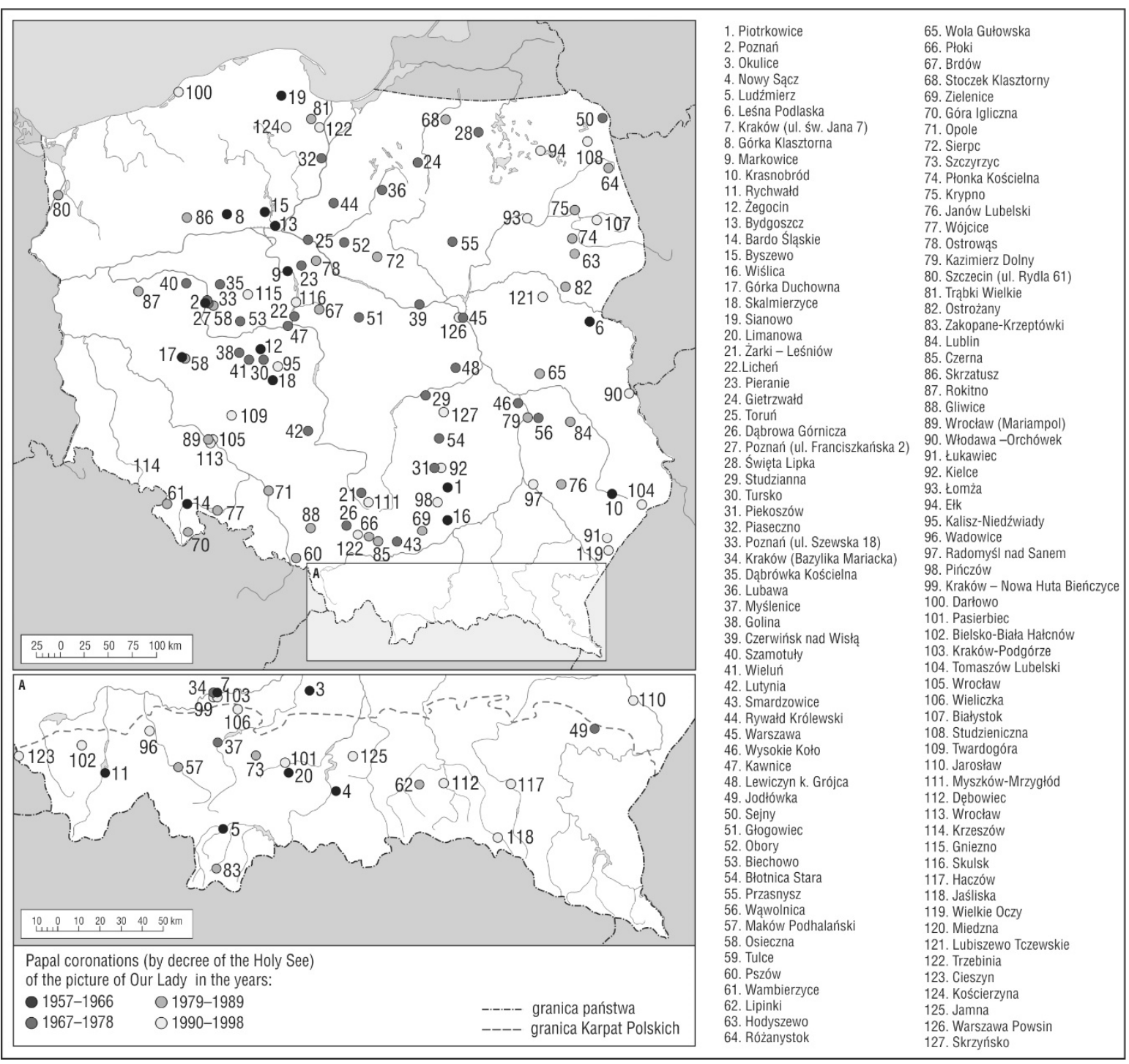

Figure 3. Papal coronations (by decree of the Holy See) of the picture of Our Lady in Poland during the Vatican II era (1948-1998). Source: author. 


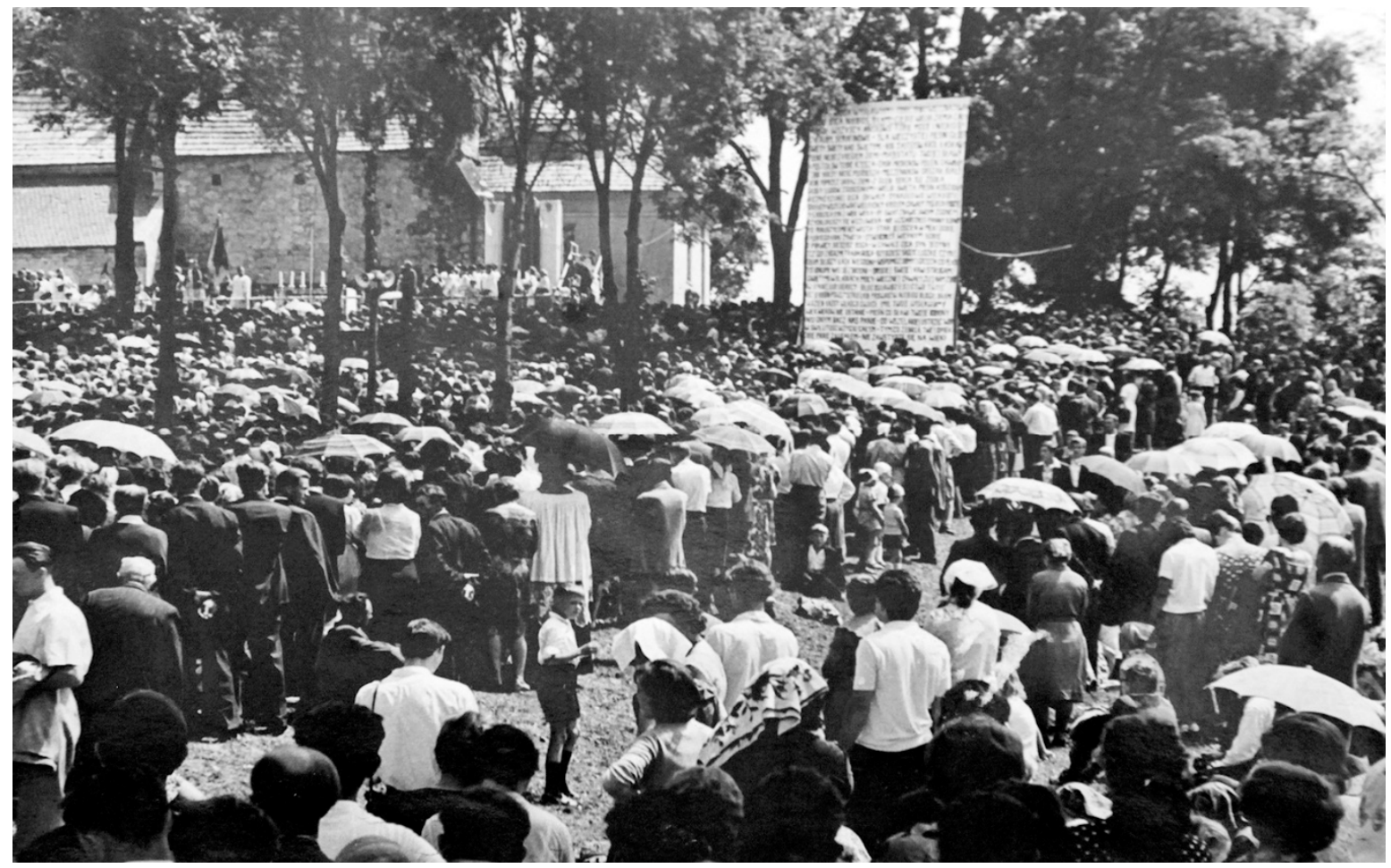

Figure 4. Celebrations of the coronation of the figure of the Mother of God of Wiślica (17 July 1966) (photo: Archives of the Sanctuary of Mother of God of Wiślica in Wiślica).

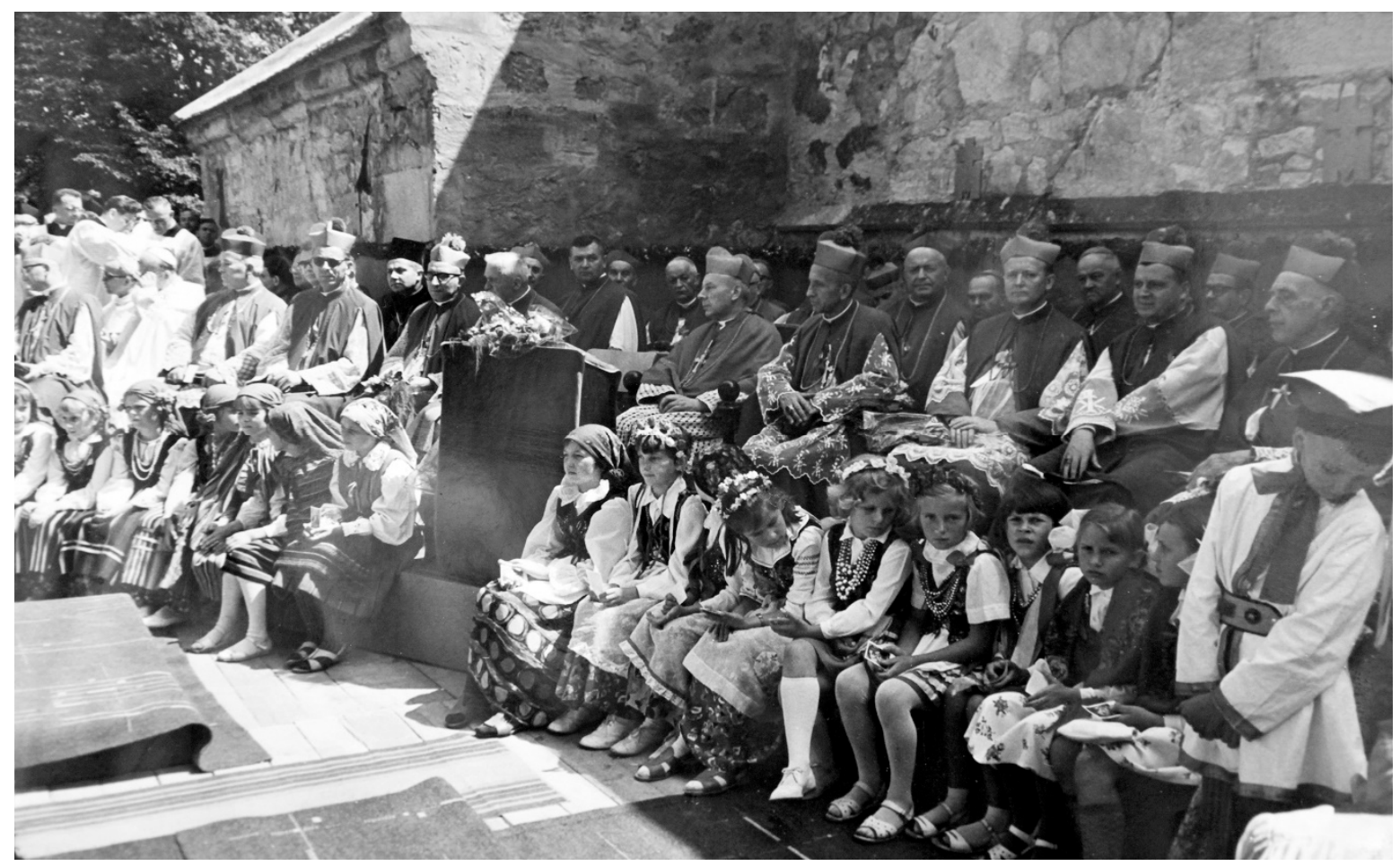

Figure 5. Celebrations of the coronation of the figure of the Mother of God of Wiślica (17 July 1966) (photo: Archives of the Sanctuary of Mother of God of Wiślica in Wiślica). 


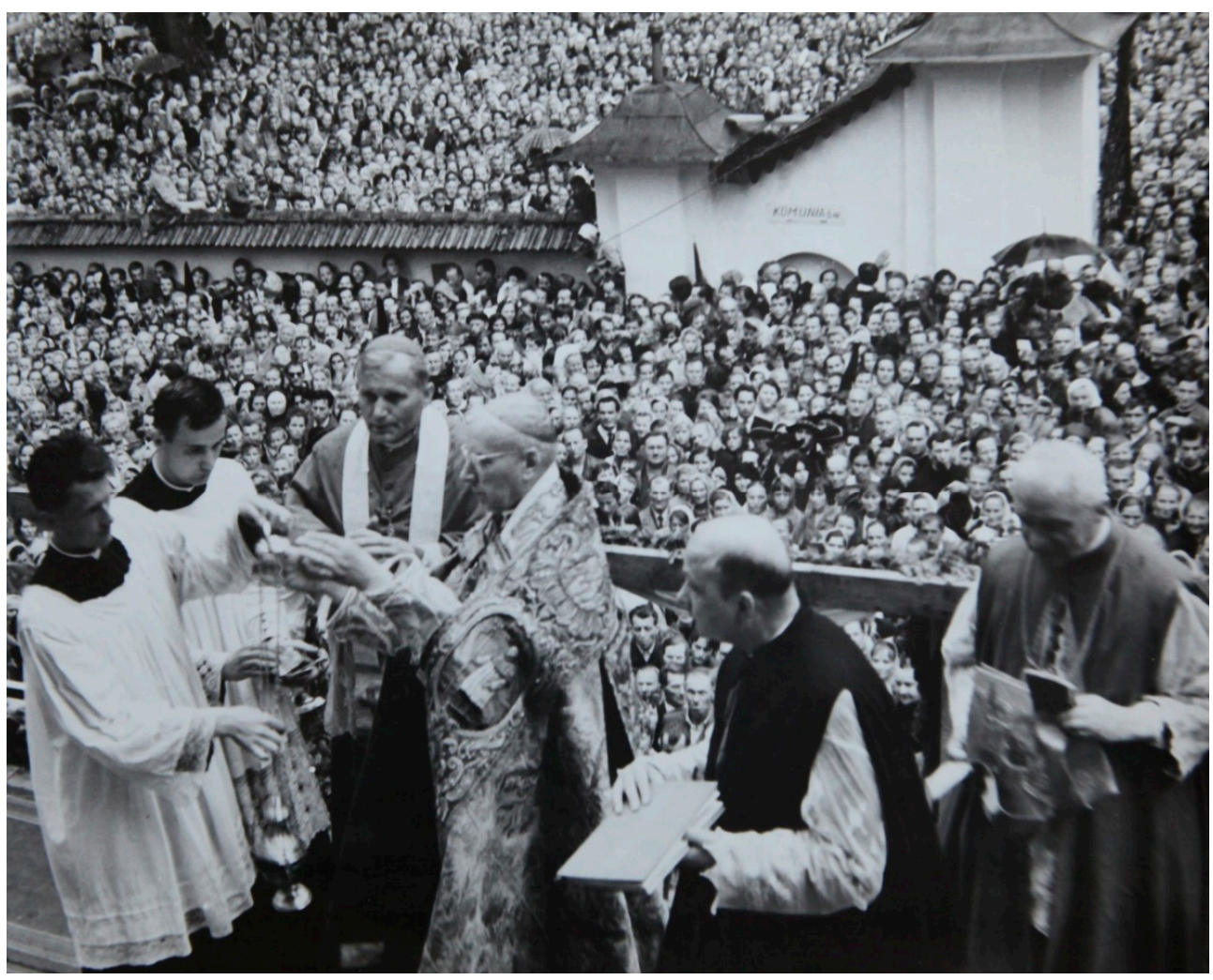

Figure 6. Celebrations of the coronation of the image of Our Lady of Rychwałd in Rychwałd (18 July 1966) (photo: Archives of the Sanctuary of Our Lady of Rychwałd in Rychwałd).

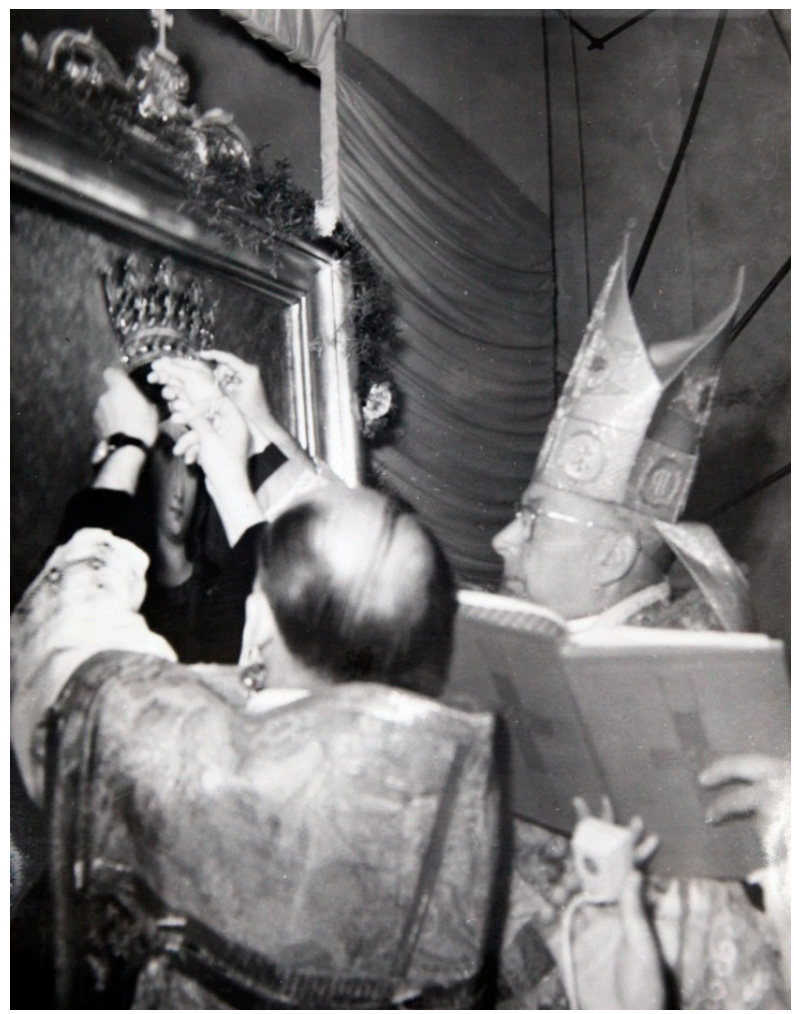

Figure 7. The Primate of Poland, Cardinal Stefan Wyszyński, crowns the image of Our Lady of Rychwałd in Rychwałd (18 July 1966) (photo: Archives of the Sanctuary of Our Lady of Rychwałd in Rychwałd). 


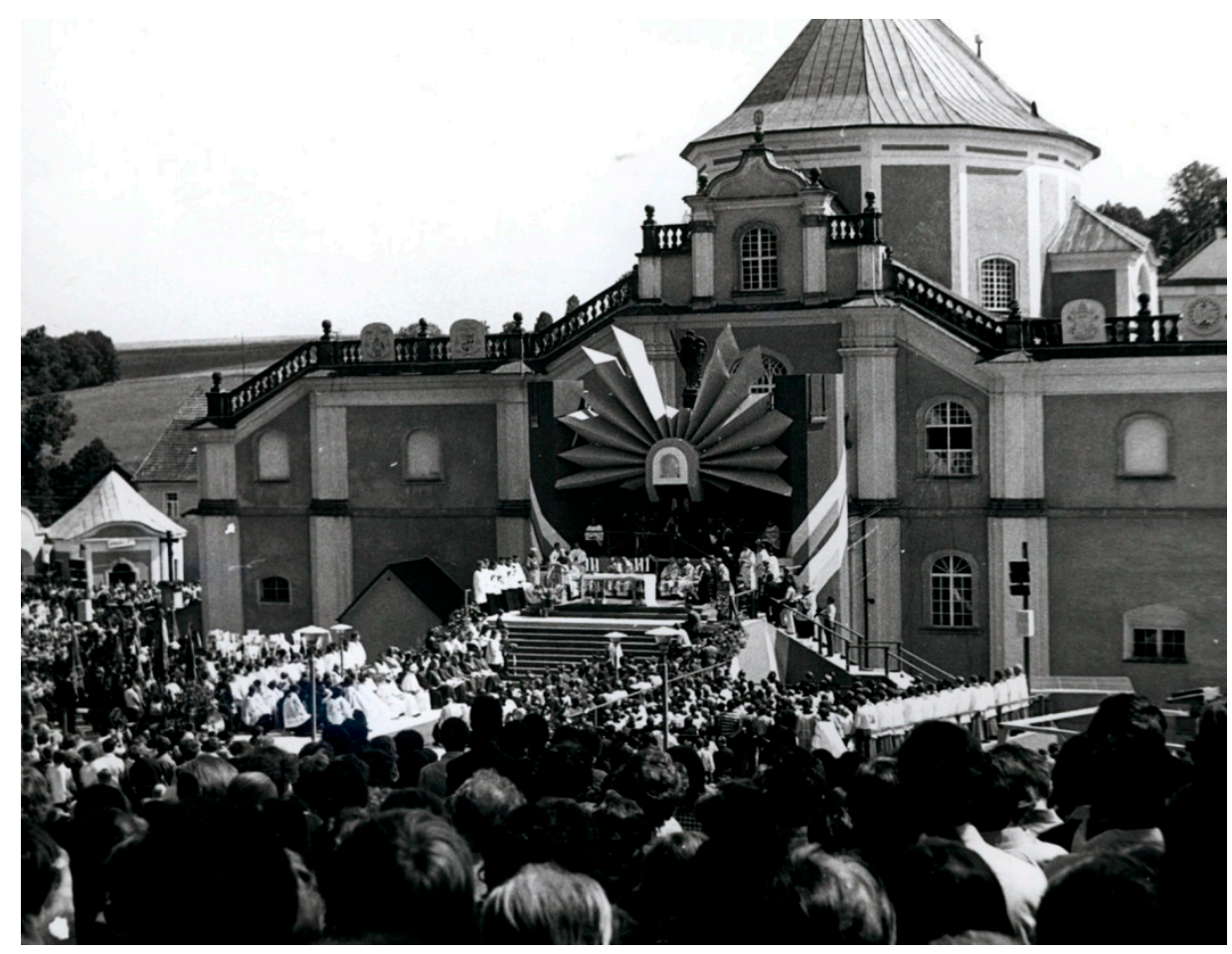

Figure 8. The ceremony of the coronation of the statue of Our Lady, Queen of Families in Wambierzyce (17 August 1980) (photo: Archwium of the Sanctuary of Our Lady Queen of Families in Wambierzyce).

As already mentioned, religious celebrations conducted by Primate Wyszyński and by Cardinal Karol Wojtyła gathered tens of thousands of faithful. The celebrations of the coronation of the image of Mary in Okulice (9 September 1962) saw the participation of approx. 80,000 people; in Nowy Sacz there were approx. 300,000 people, in Ludźmierz approx. 200,000 (Figures 9-11) in Leśna Podlaska approx. 150,000, in Górka Klasztorna 60,000, in Gietrzwałd 150,000, in Studzianna approx. 150,000 (Figure 12), in Wysokie Koło approx. 100,000, in Kawnice approx. 50,000, in Błotnica approx. 200,000, in Wąwolnica approx. 200,000, in Pszów approx. 100,000, in Różanystok approx. 300,000, in Wola Gułowska approx. 100,000, in Sejny-over 60,000 pilgrims (Figures 13 and 14).

The national pilgrimages of men, young people, women, school pupils and children to Jasna Góra, associated with the greatest celebrations in the shrine, were some of the leading elements of the pastoral strategy of the Polish episcopate. Such celebrations included the Feast of the Mother of God the Queen of Poland (3 May), the Feast of the Assumption of Mary (15 August) and the Feast of Our Lady of Jasna Góra (26 August). The largest of such national pilgrimages during that period were the following: the National Pilgrimage of the Youth (26 August 1962) with the participation of approximately 500,000 people, the National Pilgrimage of Women and Girls (26 August 1965) with the participation of more than 300,000 women, and the Pilgrimage of Men and Boys (28 August 1966) with the participation of more than 250,000 people (Jabłoński 2000). In 1982, the First Pilgrimage of the Labour World to the Shrine of Our Lady of Częstochowa was organized upon the initiative of Rev. Jerzy Popiełuszko, and it was continued in subsequent years with the participation of approximately 100,000-200,000 people each time (Jabłoński 2000).

The Divine Mercy devotion was developed after the end of WWII (Alvis 2021). In 1946, the Polish episcopate addressed the Holy See with a request to approve the Feast of Mercy based on the visions of Sister Faustina Kowalska. A similar resolution was sent to Rome by participants of the 1948 session of the Theological Society in Krakow. Due to the fact that the Holy See did not reply, the Chief Committee of the Polish episcopate sent a request to Archbishop Romuald Jałbrzykowski to give his opinion; the archbishop refused (Socha 2000). On 7 March 1959, the Supreme Sacred Congregation of the Holy Office issued 
a Notification to prohibit the popularization of the Divine Mercy image and service in the forms proposed by Sister Faustina (Figure 1). As instructed, many churches had images of the Divine Mercy either removed or repainted, and banned Divine Mercy services. With the consent of Archbishop Eugeniusz Baziak, Divine Mercy images were not removed from the Valley of Mercy in Częstochowa or from the Chapel of St. Joseph in KrakówŁagiewniki (Mróz 2008). The College of Divine Mercy was established in the Valley of Mercy in Częstochowa. It was involved in scientific research on Divine Mercy devotion and organized theological symposiums concerning the cult and its essence (Mróz 2013). Devotion to the Divine Mercy in the forms proposed by Sister Faustina Kowalska was finally revived in Poland in the late 1970s after the cancellation of the 1959 Notification by the Sacred Congregation for the Doctrine of the Faith on 15 April 1978.

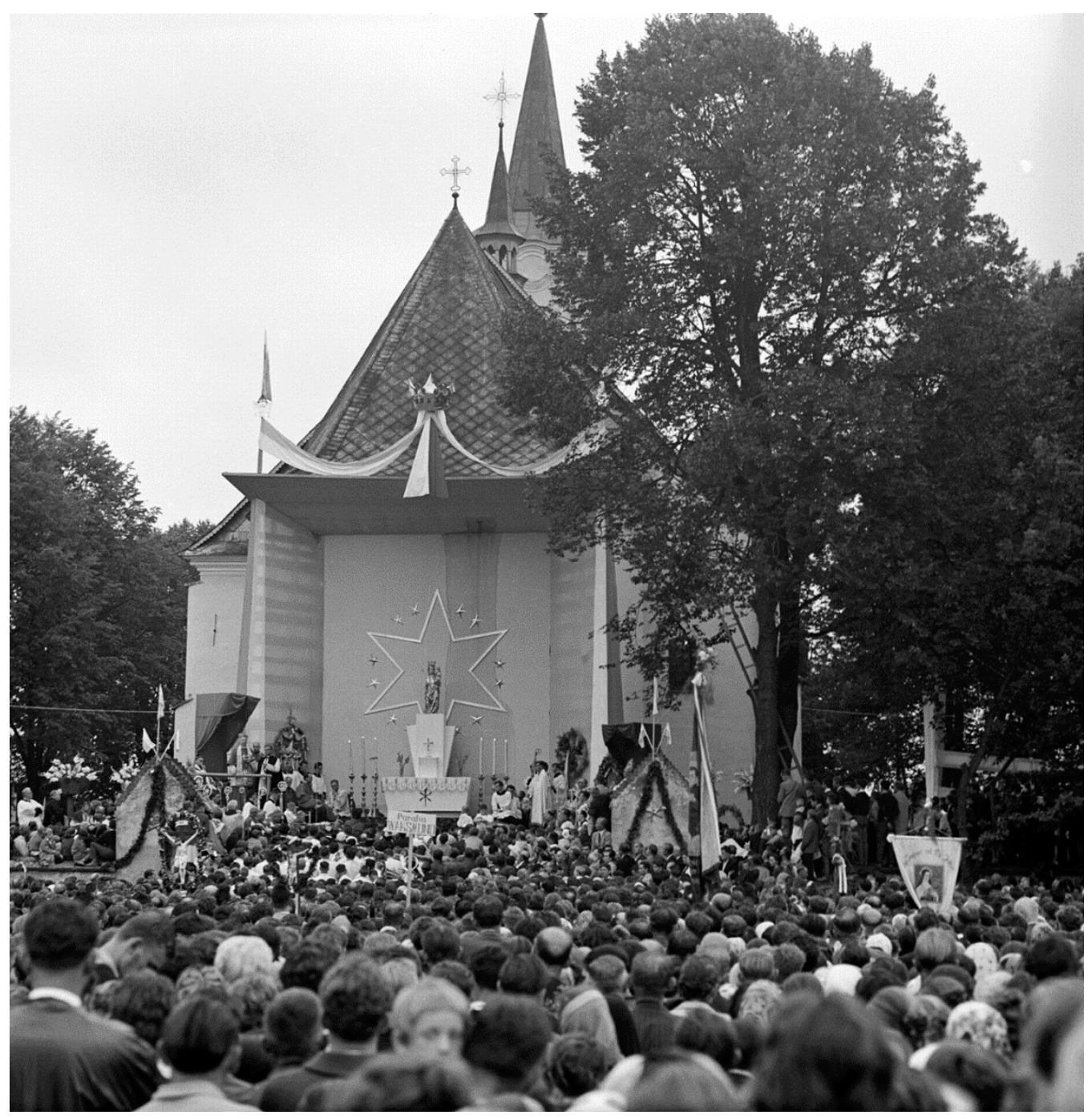

Figure 9. Celebrations of the coronation of the statue of Our Lady of Ludźmierz-Queen of Podhale in Ludźmierz (15 August 1963) (photo: Archives of the Shrine of Our Lady of Ludźmierz-Queen of Podhale in Ludźmierz). 


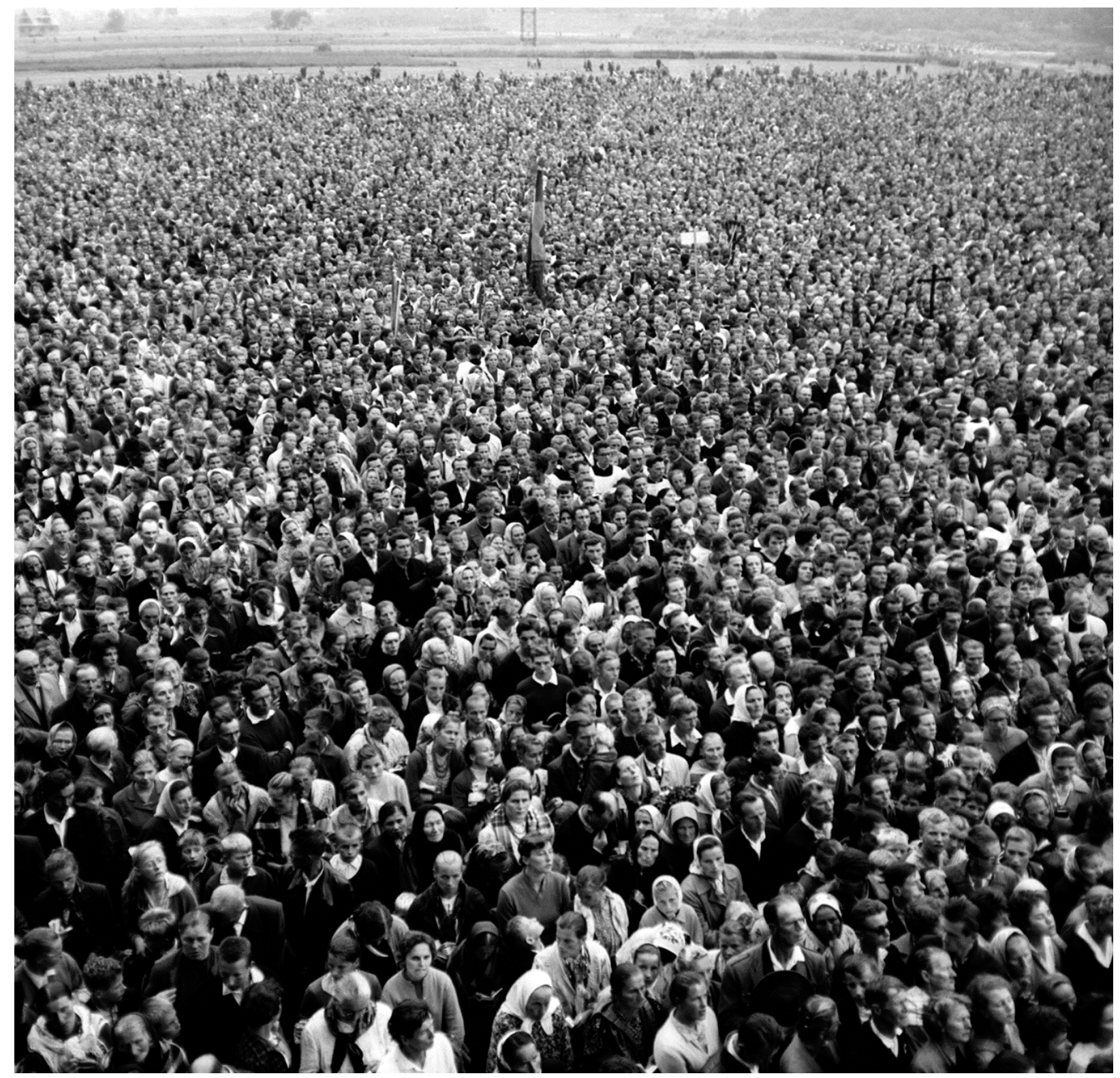

Figure 10. Celebrations of the coronation of the statue of Our Lady of Ludźmierz-Queen of Podhale in Ludźmierz (15 August 1963) (photo: Archives of the Shrine of Our Lady of Ludźmierz-Queen of Podhale in Ludźmierz). 


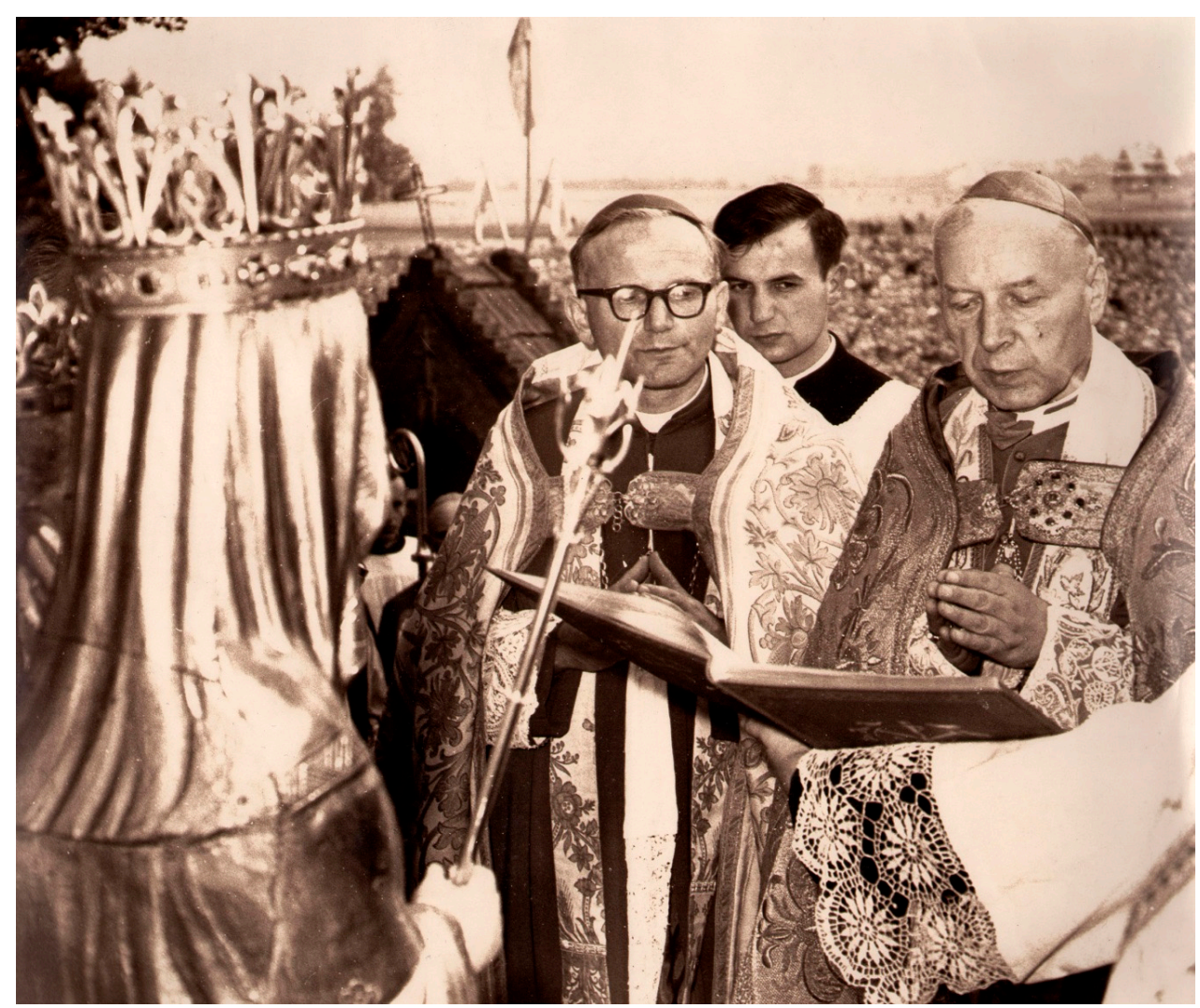

Figure 11. The Primate of Poland, Cardinal Stefan Wyszyński, crowns the statue of Our Lady of Ludźmierz-Queen of Podhale in Ludźmierz. Next to Primate Wyszyński, Card. Karol Wojtyla (15 August 1963). (photo: Archives of the Shrine of Our Lady of Ludźmierz-Queen of Podhale in Ludźmierz).

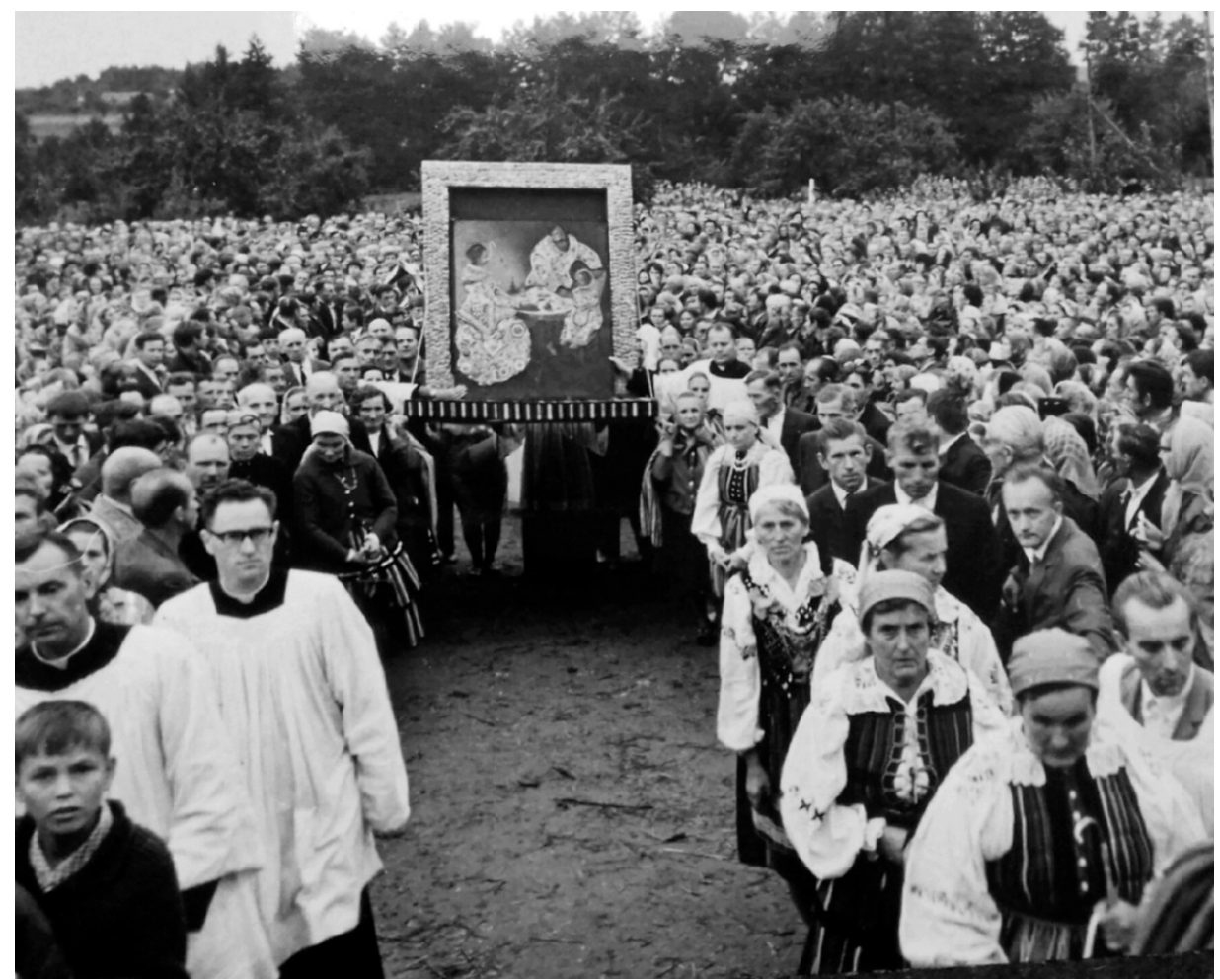

Figure 12. Celebrations of the coronation of the miraculous image of the Holy Family in Studzianna (18 August 1968) (photo: Archive of the Holy Family Sanctuary in Studzianna). 


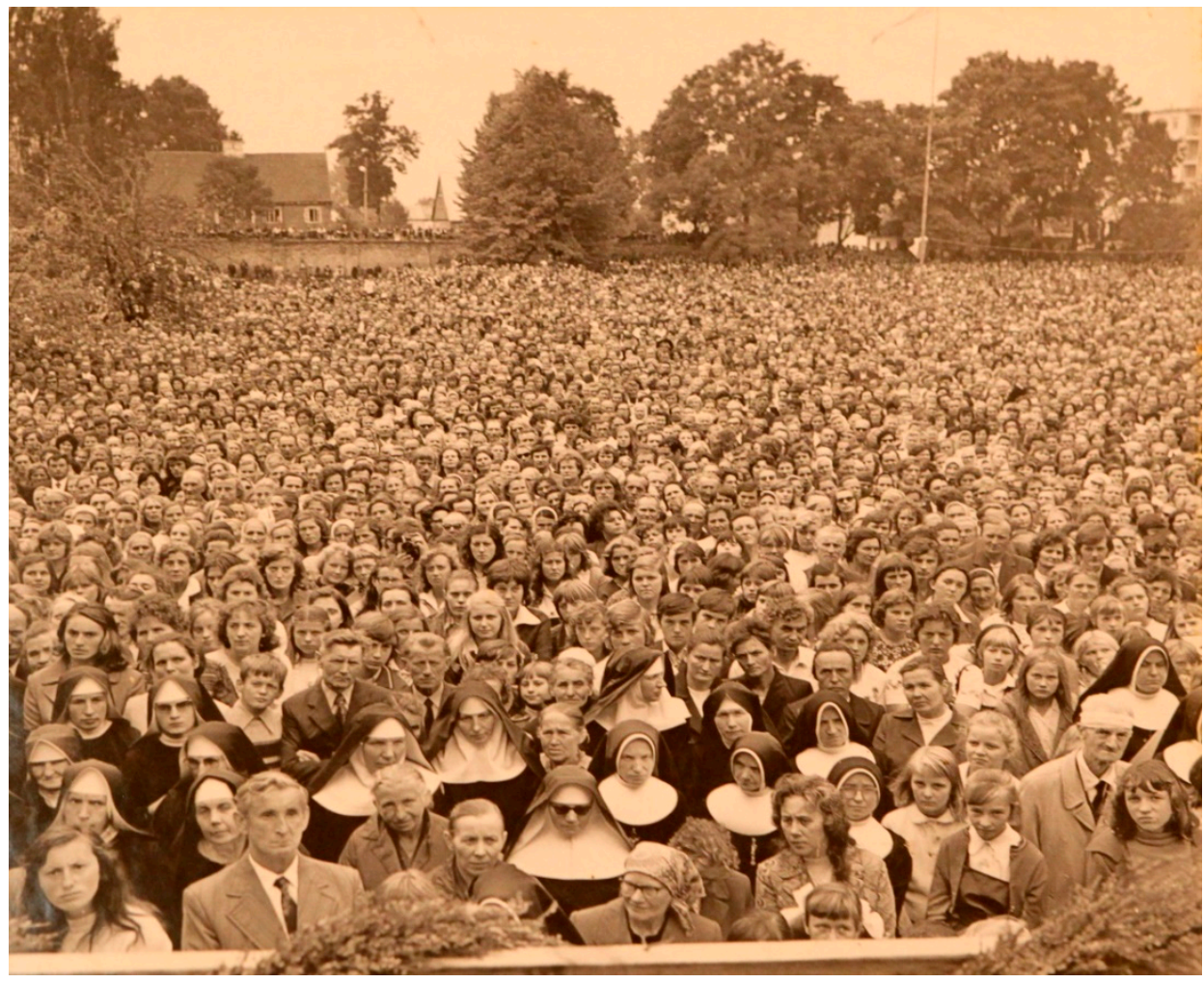

Figure 13. Over 60,000 pilgrims took part in the coronation ceremony of the statue of Our Lady of Sejny in Sejny (6 September 1975) (photo: Archive of the Sanctuary of Our Lady of Sejny in Sejny).

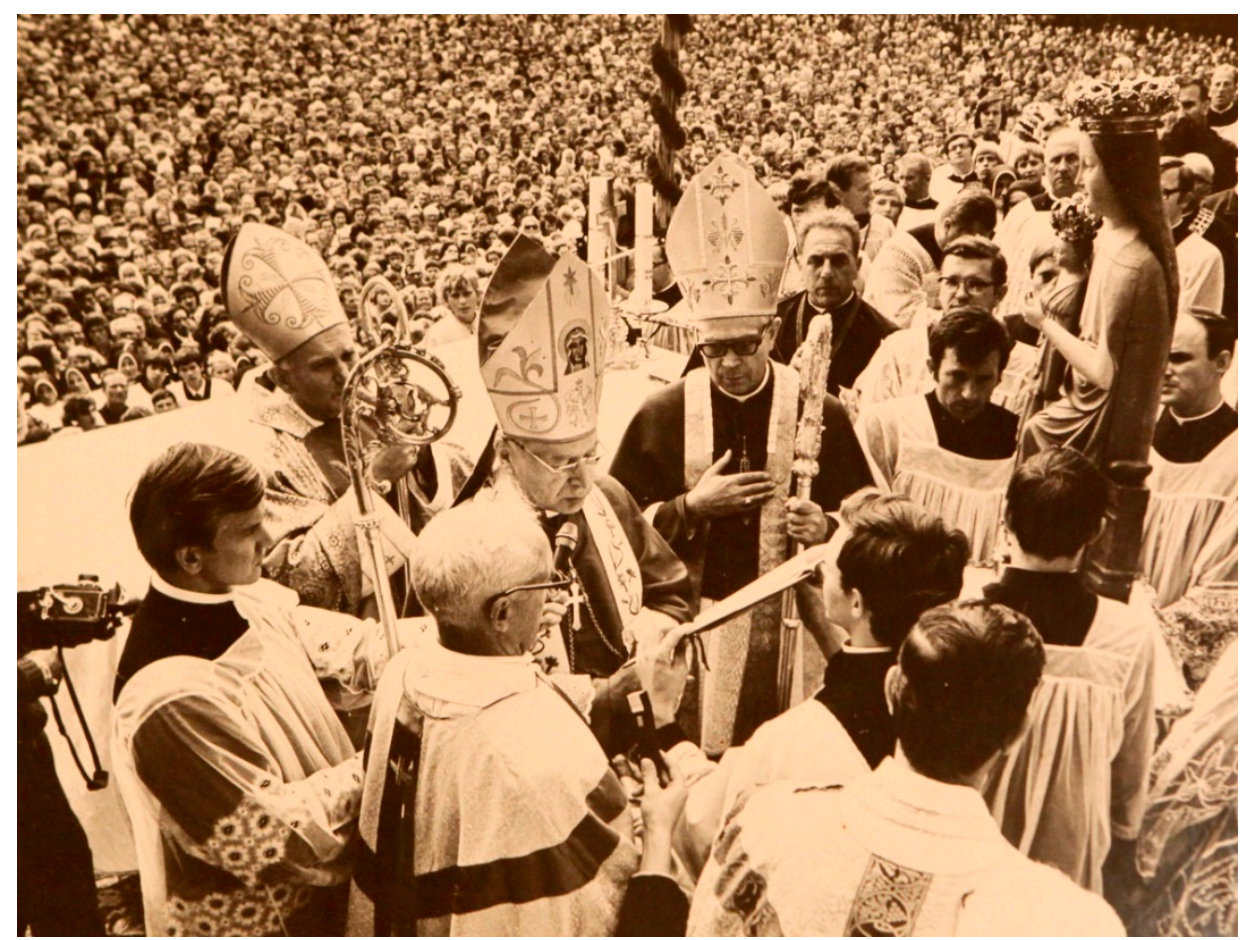

Figure 14. The Primate of Poland, Cardinal Stefan Wyszyński, crowns the statue of Our Lady of Sejny in Sejny (6 September 1975) (photo: Archive of the Sanctuary of Our Lady of Sejny in Sejny).

\subsection{Pilgrimages in Poland in the 1960s, 1970s and 1980s}

In the 1960s, pilgrimages were not only a form of public demonstration of the faith, but also a means to express resistance to communist authorities, on the part of the Polish 
people. No other country behind the Iron Country noted such processes of the development of pilgrimages and shrines as Poland did. Datko emphasizes that "only mass religiosity could have been effective in opposing the communist ideology used as a tool of oppression and enslavement", (Datko 2016). At the time, the Polish pilgrimage space was a space for prayers and debates on social, patriotic and political topics (Jackowski et al. 1999; Myszor 2008). Shrines were amongst the main bastions of faith and the Church in the communist state (Datko 2016).

It is necessary to pay attention to the attitudes of communist authorities towards organizers of pilgrimages and to pilgrims. The authorities of the Polish People's Republic issued administrative ordinances that were supposed to hinder or even disable the organization of pilgrimages, especially walking pilgrimages, to sacred places. Vehicle traffic was restricted, and scheduled journeys on trains, buses and trams along the routes to pilgrimage sites were cancelled. The militia carried out thorough road inspections, recorded vehicle registration cards, noted and photographed registration plates of vehicles in shrine car parks, and then took measures against the pilgrims who were the owners of those vehicles. Authorities organized cultural events and entertainment for local communities that were designed to compete with traditional pilgrimages. In order to draw the faithful away from participation in pilgrimages, party and state authorities organized football games of first-league teams, as well as international games, speedway rallies, free trips to tourist attractions, and attractive TV broadcasts, to entice people to stay home. The militia and the security service persecuted, detained and inspected pilgrims. Lay pilgrim guides were frequently arrested and taxi drivers were prohibited from carrying the faithful during church fairs (Jackowski et al. 1999; Kopiczko 1996; Myszor 2008; Datko 2016). Numerous documents (which were confidential at the time) evidence the scale of the efforts taken by communist authorities to thwart the plans of pilgrims and the organizers of pilgrimages.

Officers of the Department of Security also took more extreme measures. Group " $\mathrm{D}$ " functioned in the Fourth Department of the Ministry of Internal Affairs after 1973 and took "special steps" against pilgrims going to Jasna Góra. Grzegorz Piotrowski, who later killed Rev. Jerzy Popiełuszko, was one of these officers. Piotrowski was given the order to burn the barn of the host of pilgrims, to attempt to rape the host's daughter, and to contaminate his well during the pilgrimage of students to Jasna Góra (Dziurok 2008, p. 10). A tragic example was the use of napalm to set fire to the miraculous image of the Holy Mother of Stara Wieś in the shrine in Stara Wieś on 6 December 1968. The arsonist was never found. On 11 August 2006 the Institute of National Remembrance officially confirmed that the image was burnt by the Department of Security and the event was classified as a communist crime. The replica of the image was re-crowned (with the saved golden crowns dating back to 1877) on 10 September 1972 by the Primate of Poland, Cardinal Stefan Wyszyński, and Bishop Ignacy Tokarczuk (Mróz and Mróz 2015; Mróz 2018).

The communist authorities of the Polish People's Republic also hindered walking pilgrimages to the shrine in Jasna Góra. The only pilgrimage tolerated was the Warsaw Walking Pilgrimage to Jasna Góra (dating back to 1711), which became the all-Poland pilgrimage in the 1960s, and in the 1970s won international recognition. In 1969, approximately 8000 pilgrims participated in this pilgrimage, in 1976 18,000, and in 1977 almost 25,000 people (Wlaźlak and Sznajder 2009, p. 20). The propaganda of state authorities conveyed the message that the organization of the pilgrimage was a manifestation of civic and religious freedom in Poland. However, the Warsaw Walking Pilgrimage was under the constant surveillance of around 60 agents and officials of the Security Service. Additionally, secret collaborators were recruited. They were offered substantial pay for their operational intelligence activities. For example, in 1981, the Ministry of Internal Affairs paid 300-500 zlotys for ordinary information, 1000-2000 zlotys for accounts of attendance at a Holy Mass, and 3000 zlotys for a tape recording (in 1981, an average monthly salary in the national economy amounted to 7689 zlotys) (Jabłoński 2000); www.stat.gov.pl (accessed on 26 May 2021). 
The celebrations of the Holy Year 1975 were another important factor affecting the development of pilgrimages in Poland during the Vatican II era. In order to facilitate the grace of indulgences for all the faithful around the world, Pope Paul VI declared the year 1974 to be a Holy Year for all countries worldwide, except for Italy and the Vatican. In Poland, pilgrimage centers where it was possible to obtain the Holy Year indulgence, after fulfilling the prescribed conditions, were designated (Kupiszewska 2014).

Devotion to the Holy Cross, the Passion and the Holy Sepulchre was one of the main characteristics of Polish religiosity during the Vatican II era. Several new Calvary shrines and shrines of Passion were established during that period: in Lichen, Serpelice, Ujście nad Notecia, Oborniki Wielkopolskie and Krasnobród, the Ecce Homo Shrine of St. Albert Chmielowski in Krakow, and the Shrine of the Holy Cross in Olecko and Rekszowice. The shrine in Rekszowice was built in expiation for the profanation of the cross by officers of the militia and ORMO (Volunteer Reserve of the Citizen's Militia) in April 1966. Cross segments that were cut by communists can be found in the shrine, on the main wall of the chancel, and incorporated in the scene of the Last Judgment (Mróz 2021a, p. 183). In 1951, the Chapel of the Holy Sepulchre in Miechów, the oldest shrine of the Lord in Poland, was restored and prepared for veneration. In 1969, after a break of more than 120 years, devotion to the Holy Sepulchre was revived at the shrine in Przeworsk (Mróz 2000).

When it comes to shrines of the Lord, the greatest development in pilgrimages was noted in the Passion and Marian shrine in Kalwaria Zebrzydowska, and in the Shrine of the Holy Cross in Kraków-Mogiła. In August 1974, Cardinal Wojtyła wrote a letter to the residents of Krakow requesting them to go on a pilgrimage to the shrine in Mogiła on 15 September. More than 150,000 people responded to the Cardinal's call, mostly coming on foot. This was the First Expiatory Pilgrimage of the residents of Krakow to Mogiła (Mróz 2021a).

The constantly increasing pilgrimage movement is exemplified in the national shrine of Poland in Jasna Góra, but also in dozens of Marian shrines, shrines of the Lord, and shrines of saints and beati. In 1983, Poland celebrated the 600th anniversary of the convent in Jasna Góra. Some of the walking pilgrimages to Jasna Góra were initiated then (e.g., the Kashubian Pilgrimage) (Jackowski et al. 1999). The pilgrimage of men to the shrine of Our Lady in Piekary Ślaskie was especially important at the time. It saw the participation of more than 100,000 pilgrims each year, and often witnessed speeches by Cardinal Karol Wojtyła. During the 1970s, $12.5 \%$ of the population of Poland participated in religious pilgrimages, increasing to $15 \%$ during the 1980 s (Jackowski et al. 1999).

The greatest numbers of visitors in the history of the Marian Shrine of Jasna Góra were recorded in 1979 (the first pilgrimage of John Paul II to Poland) and in 1991, when the Sixth World Youth Day was held from 10 to 15 August in Czesstochowa, with the attendance of Pope John Paul II and approximately one and a half million young people from 77 countries worldwide. The estimated number of pilgrims amounted to 6-8 million people in each of these years (Jabłoński 2000). The number of participants in walking pilgrimages to Jasna Góra rapidly grew after 1977, and reached a record high in 1991 when 400,000 pilgrims came on foot to the World Youth Day organized in Czesstochowa (Jackowski 2005). Numerous pedestrian pilgrimages to Jasna Góra were initiated for the 600th jubilee of the Jasna Góra convent, celebrated in 1983, e.g., the Kashubian pilgrimage from Swarzewo to Częstochowa, "600 kilometres for the 600th anniversary" (Jackowski et al. 1999, p. 166).

The beatification on 17 October 1971 by Pope Paul VI of Maximilian Maria Kolbe, and his subsequent canonization by Pope John Paul II on 10 October 1982, influenced the development of pilgrimages to the shrine of the saint in Niepokalanów. However, it should be emphasized that pilgrimages to the site had been increasing since 1954, when the construction of a large Basilica of Blessed Virgin Mary the Immaculate, the Mediatrix of All Graces, was finished. The Primate of the Millennium, Cardinal Stefan Wyszyński, visited the shrine 37 times.

From 3 November 1984, the tomb of Rev. Jerzy Popiełuszko (1947-1984), the chaplain of "Solidarity", who was brutally murdered on 19 October 1984 by Security Service offi- 
cers, became a new Polish pilgrimage site of international importance. The tomb of Rev. Popiełuszko can be found in the Church of St. Stanislaus Kostka in Warsaw. According to data from the Documentation Centre of the Life and Cult and Shrine of Blessed Rev. Jerzy Popiełuszko in Warsaw, his tomb was visited during the period from 1984 to the end of 2019 by almost 23 million people, including Pope John Paul II, Cardinal Joseph Ratzinger, President of the USA George Bush, Prime Minister of Great Britain Margaret Thatcher and President of the Czech Republic Václav Havel (www.niedziela.pl/artykul/46270/Zpotrzeby-serca-\%E2\%80\%93-kult-ks-Jerzego; accessed on 11 January 2021).

From 4 to 18 June 1989, the first partially free parliamentary election after WWII was held in Poland. The result of the election is considered to have been the decisive moment in the commencement of political transformation in Poland, which marked the beginning of a new stage in the functioning of pilgrimage centers and the dynamic development of pilgrimages in Poland. Subsequent years saw the transformation of the tourism economy into a market-oriented economy.

In 1988, before the transformation, there were around 500 shrines in Poland-over 380 Marian shrines, 70 shrines of the Lord Jesus Christ, and 48 shrines of saints and beati. During the period from 1948 to 1988, 70 new shrines were established in Poland and 20 shrines regained their cult, resulting in a renaissance of pilgrimages, which had been hindered by the partition of Poland and WWII (Figure 15).

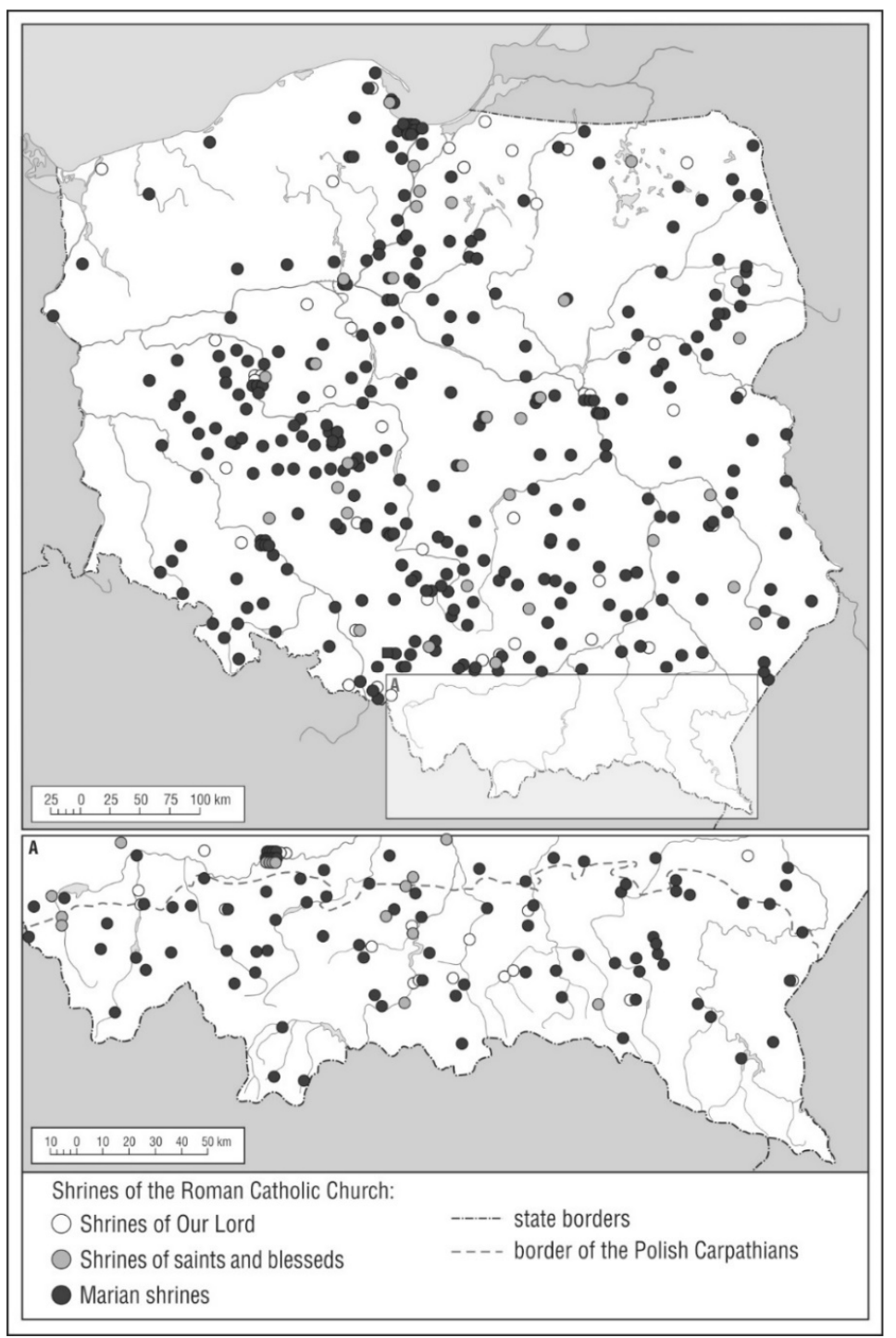

Figure 15. Shrines of the Catholic Church in Poland in 1989. Source: author. 
The pilgrimages of Pope John Paul II to Poland and the beatifications or canonizations of figures from Poland by the Pope had an immense influence on the development of Polish shrines, and on the distinct development of pilgrimages and religious tourism during the period of 1990-1998 (Mróz 2014). During his pontificate, John Paul II made eight pilgrimages to Poland. Six of them occurred during the Vatican II era under discussion here (in 1979, 1983, 1987, 1991, 1995, and 1997). In the course of these six pilgrimages to Poland, Pope John Paul II visited more than 30 shrines (Jackowski and Sołjan 2005). On his pastoral visits to Poland, Pope John Paul II crowned 21 images of the Mother of God (Jodłówka, Łukawiec, Kielce, Łomża, Ełk, Kalisz-Niedźwiady, Wadowice, Darłowo, Wrocław, Krzeszów, Gniezno, Skulsk, Haczów, Jaśliska, Wielkie Oczy, Jamna, Wejherowo, Warszawa, Jaworzno, and Wadowice i Bydgoszcz). It should be emphasized that during his pontificate, John Paul II canonized 9 Poles and beatified 155 (www.opoka.org.pl/biblioteka/ $\mathrm{T} / \mathrm{TH} / \mathrm{THO} / 25 \mathrm{jp} /$ turek_kanonizacje.html; accessed on 29 January 2021). As a result of these canonizations and beatifications, new shrines were established in Poland.

On 18 April 1993, Pope John Paul II beatified Sister Faustina Kowalska, the Apostle of Divine Mercy, who was later canonized on 30 April 2000. The first shrine of Divine Mercy in Poland was established in Czestochowa in 1992. During the Vatican II era, before the end of 1998, five more shrines were established in Poland (Kraków-Łagiewniki, Szczecin, Myślibórz, Kalisz and Ożarów Mazowiecki) (Mróz 2021a).

\subsection{The Polish Pilgrimage Space from the Political Transformation of 1989}

The Polish pilgrimage space, comprising the Polish network of shrines and pilgrimage routes, was considerably transformed following the political transformation of 1989 to 1998. From early 1990 to 31 December 1998, 66 new shrines were established with the approval of the local ordinary in accordance with Canon 1230 of the Code of Canon Law. The greatest increase in the number of new shrines was noted in the case of shrines of saints and beati, and in the group of shrines of Our Lord. The establishment of new shrines in Poland was also associated with the development of the cult of the Divine Mercy, and the renewal of the cult of saints and beati who experienced great popularity among members of the faithful in the Middle Ages, e.g., St. Anthony (in Brodnica, Czesstochowa, Dabrowa Górnicza Jasło, Koziegłówki, Mińsk Mazowiecki), St. Adalbert (Bieliny, Cieszęcin, Gdańsk, Gorzęziej k. Tczewa), and St. Joseph (Nisko, Prudnik). It should also be stressed that the development of the cult of Our Lady of Fatima led to the establishment of 14 shrines of Our Lady of Fatima (Braniewo, Biskupiec Reszelski, Elblag, Ełk, Górki k. Gawrolina, Kraków, Korsze, Lubajny, Olsztyn, Rozogi, Sosnowiec, Trzebinia, Węgrów), whereas the development of the cult of Our Lady of La Salette resulted in the establishment of the shrines in Debowiec, Gdansk-Sobieszewo and Rzeszów, and the development of the cult of Our Lady of the Gate of Dawn resulted in the establishment of the shrine in Gdańsk, Skarżysko-Kamienna and Warsaw. The first decade following the political transformation in Poland was also marked by intensified coronations of Marian images. During the period from 1990 to 1998, 37 coronations of images of the Blessed Virgin Mary were held in Poland based on a papal bull.

The first decade after the political changes in Poland also saw increased coronations of Marian images. In the years 1990-1998, 37 coronations of images of the Blessed Virgin Mary, on the basis of a papal bull, took place in Poland.

From the early 1990s, regional and local pilgrimage routes associated with John Paul II were established. Papal Routes covered hiking routes (mainly in the mountains), bicycle routes and kayak routes, which had been used by the then Rev. Karol Wojtyła (Mróz 2014). Various shrines began to gradually extend the pilgrimage infrastructure, and underwent renovation works that were almost impossible during the era of Communism. Moreover, it must be stressed that, since the 1990s, pilgrimages of Poles to shrines abroad (mainly Rome, Loreto, Assisi, Vilnius, Lourdes, and Fatima) have also developed (Ogórek 2006).

On 31 December 1998, almost 35 years after the Second Vatican Council ended, there were more than 560 Catholic shrines in Poland, including over 420 Marian shrines, 
70 shrines of Our Lord, and more than 70 shrines of saints and beati. The largest number of shrines could be found in the Polish Carpathians (more than 110 shrines), and also in Wielkopolska, Warmia and Mazowsze. There were also new shrines created in the areas of western and northern Poland (Figure 16).

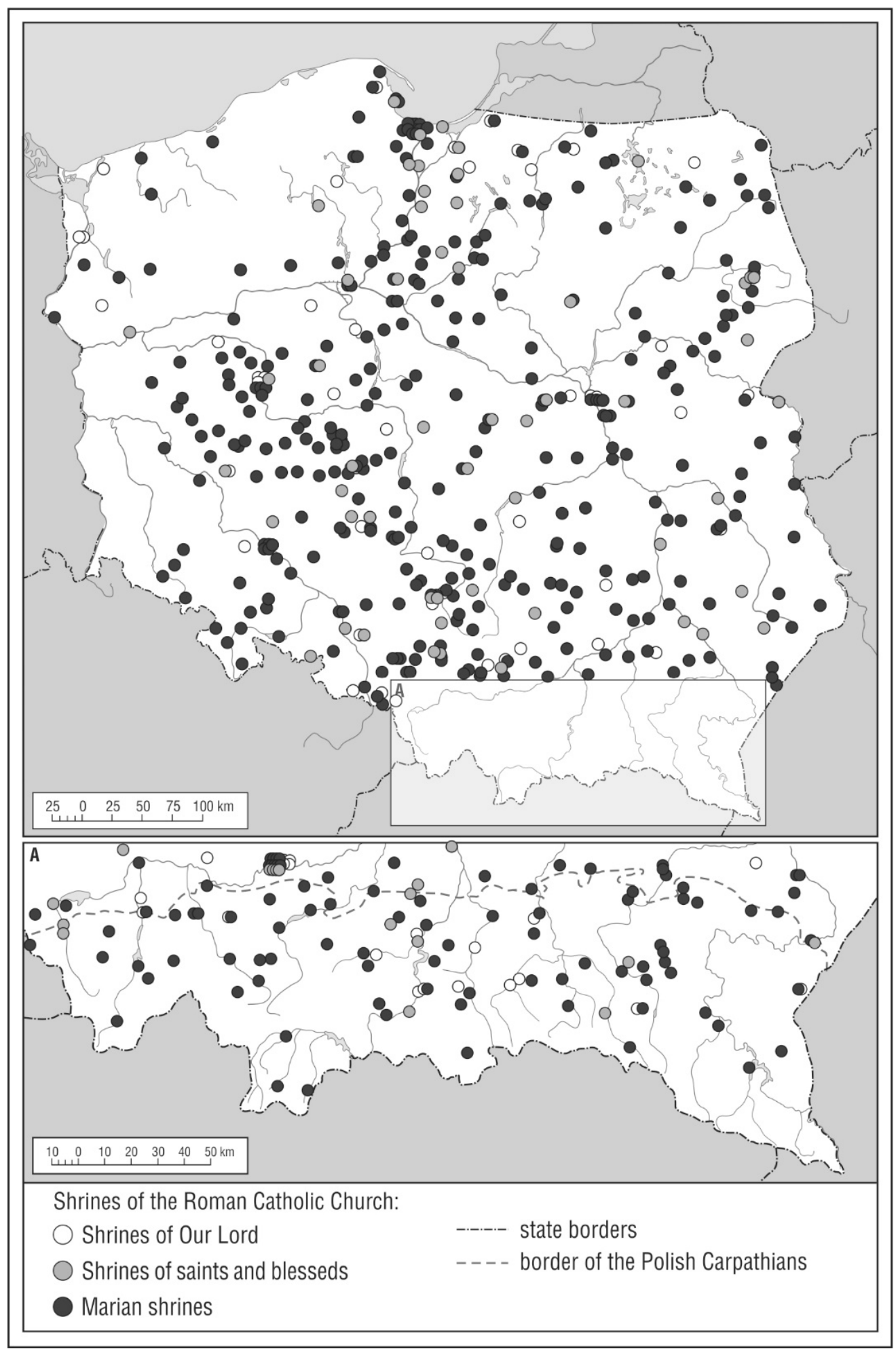

Figure 16. Shrines of the Catholic Church in Poland in 1998. Source: author. 


\section{Discussion}

A detailed analysis of changes in the pilgrimages in Poland during the Vatican II era, and the discussion of factors affecting these transformations, is a challenging scientific venture. Out of necessity, this study has a much more modest scope. As a result of field research, library queries and archive queries, the author managed to analyze the network of shrines functioning during the Vatican II era in quantitative and qualitative terms, and has indicated, among other things, the number of shrines functioning in 1948, 1989 and 1998. The analyses presented in this study differ from previous publications on the matter. The number of shrines quoted by the authors of previous studies concerning the network of shrines in Poland seems very general, and mostly based on the network of Marian shrines. In the statistical annals of the Catholic Church in Poland, published in 1991, M. Ziółkowski mentioned that "pilgrimage sites in Poland include around 500 shrines, where more than 400 of them are Marian shrines" (Ziółkowski 1981, p. 224). Z. Jabłoński, in turn, argued that in 1999 there were 474 Marian shrines in Poland, including 120 shrines established based on a replica of the image of Our Lady of Jasna Góra (Jabłoński 2000, p. 160). In his numerous studies on pilgrimages in Poland, A. Jackowski wrote that "there are more than 500 pilgrimage shrines registered in Poland, with the predominance of Marian shrines (in a total number of 430)", (Jackowski 2005, p. 62). Research by these authors does not actually refer to the network of shrines of Our Lord or shrines of the saints and beati.

The analysis of the development of pilgrimages and shrines in Poland during the Vatican II era as presented in this paper inclines the author to conclude that it was a special and dynamic period in the history of Polish pilgrimage. Since the 1960s, pilgrimages in Poland have experienced exponential growth. The process was associated with preparations for the celebrations of the millennium of Christianity in Poland (1966), and was undoubtedly influenced by Vatican II. Two fathers of the Council-the Primate of Poland, Cardinal Stefan Wyszyński, and Cardinal Karol Wojtyła, elected Pope on 16 October 1978-were of key importance to the development of pilgrimages and shrines in Poland.

In the early 1980s, shrines and pilgrimages rapidly developed. This was mainly the consequence of the appointment of the Metropolitan Bishop of Krakow, Cardinal Karol Wojtyła, as the Pope, the apostolic visits of John Paul II to his homeland, and the development of the Divine Mercy devotion, as well as beatifications and canonizations of new Polish saints and beati. The next stage in the history of pilgrimages in Poland began with the 1989 political transformation. As a result, the network of shrines in Poland further developed, new pilgrimage routes were created, and the pilgrimage infrastructure was extended. The following factors seem to be of the greatest importance to the functioning of shrines after 1989: pilgrimage traditions; pastoral attitudes and the entrepreneurial attitudes of custodians/rectors of shrines; the pastoral program of a given shrine; historical, cultural and architectural values; the promotion of shrines in the mass media; the improved accessibility of the shrine to transport routes; and the development of the automotive industry. In 1980, for example, 2,383,000 passenger cars were registered in Poland, with the number more than tripling to 9,991,000 twenty years later (Leszczyńska 2018, p. 263).

In subsequent studies regarding shrines and pilgrimages during the Vatican II era in Poland, attention should be paid to forgotten shrines, the cults of which disappeared during that period. It would certainly be interesting to compare the origins and the functioning of Polish shrines during the Vatican II era with shrines in the countries of Central and Eastern Europe.

\section{Materials and Methods}

From in-house studies, including archive queries and library queries, the analysis of sources, and the collection of factual materials, transformations in the pilgrimage space of Poland during the Vatican II era have been determined. Source materials from archives of more than 50 shrines, in more than 20 church archives (diocesan and convent archives) and state archives, and in several Krakow libraries, were used. Official journals published by individual dioceses of the Roman Catholic Church, diocesan annals (also published with 
other titles: Elenchus, Rocznik, Katalog or Spis) and annals of male and female congregations were important sources of information used to prepare this paper. The catalogue of Rev. Wincent Zaleski titled "Sanktuaria Polskie. Katalog encyklopedyczny miejsc szczególnej czci Osób Trójcy Przenajświętszej, Matki Bożej i Świętych Pańskich", (catalog title translated from Polish into English: "Polish Shrines. An Encyclopaedic Catalogue of Sites of Particular Devotion of the Holy Trinity, Mother of God and Saints"), elaborated after the death of its author by Maria and Jacek Łepicki and published in 1988, was a valuable publication used as a point of reference when verifying the list of shrines functioning in 1989. The publication contains a catalogue of Marian shrines, shrines of the Lord, and shrines of saints (Zaleski 1988).

In order to collect information about shrines, apart from basic field research methods such as observations or descriptions based on this researcher's own experience, there was also a need to conduct interviews with shrine custodians, shrine staff, and residents of cities, towns or villages where these shrines are located. Such qualitative data are only briefly mentioned in the article. During the last twenty-five years, the author has conducted field research at more than 400 shrines in Poland.

The materials and statistical data collected during the research were systematized and collated in tabular and graphic form. Cartography was used in the elaboration of both quantitative and qualitative data. The presentation of research problems on maps enabled the author to analyze regularities in the spatial diversity of the examined phenomena. Descriptive-analytical and dynamic-comparative methods were used to analyze research results.

Funding: This research received no external funding.

Data Availability Statement: https://www.researchgate.net/profile/Franciszek-Mroz (accessed on 30 June 2021).

Conflicts of Interest: The author declares no conflict of interest.

\section{References}

Alvis, Robert E. 2021. The Tenacity of Popular Devotions in the Age of Vatican II: Learning from the Divine Mercy. Religions 12: 65. [CrossRef]

Bartnik, Czesław. 1987. Vaticanum II jako wydarzenie historyczne i doktrynalne. In W dwudziestolecie Soboru Watykańskiego II. Recepcjadoświadczenia - perspektywy. Edited by Józef Homerski and Franciszek Szulc. Lublin: Towarzystwo Naukowe Katolickiego Uniwersytetu Lubelskiego, pp. 41-58.

Bowman, Marion, Dirk Johannsen, and Ane Ohrvik. 2020. Reframing Pilgrimage in Northern Europe: Introduction to the Special Issue. Numen 67: 439-52. [CrossRef]

Chélini, Jean, and Henry Branthomme. 1982. Les chemins de Dieu. Histoire des pèlerinages chrétiens des origines à nos jours. Paris: Hachette.

Cohen, Erik. 1992. Pilgrimage centres: Concentric and excentric. Annals of Tourism Research 19: 33-50. [CrossRef]

Coleman, Simon, and John Eade. 2004. Reframing Pilgrimage. Cultures in Motion. London: Routledge.

Collins-Kreiner, Noga. 2010. Researching Pilgrimage: Continuity and Transformations. Annals of Tourism Research 37: 440-56. [CrossRef]

Datko, Andrzej. 2016. Chrześcijańskie miejsca pielgrzymkowe w Polsce. In 1500 lat chrześcijaństwa w Polsce. Edited by Paweł Ciecielag, Bożena Łazowska, Piotr Łysoń and Wojciech Sadłoń. Warszawa: Główny Urząd Statystyczny, Instytut Statystyki Kościoła Katolickiego, pp. 160-87.

Digance, Justine. 2003. Pilgrimage at contested site. Annals of Tourism Research 301: 143-59. [CrossRef]

Doburzyński, Dariusz. 2021. Znak drogi. Teologia pielgrzymowania z perspektywy Camino de Santiago. Torun: Wydawnictwo Naukowe Uniwersytetu Mikołaja Kopernika.

Dyas, Dee. 2020. The Dynamics of Pilgrimage. London: Routledge.

Dziurok, Adam. 2008. Grupa “D”, czyli esbecy do zadań specjalnych. Gość Niedzielny 2008: 10.

Eade, John. 1992. Pilgrimage and tourism at Lourdes, France. Annals of Tourism Research 19: 18-32. [CrossRef]

Eliade, Mircea. 1969. The Quest: History and Meaning in Religion. Chicago: University of Chicago Press.

Fridrich, Alfred. 1904. Historye cudownych obrazów Najświętszej Maryi Panny w Polsce, t. II. Kraków: Wydawnictwo Towarzystwa Jezusowego.

Gładyś, Beata, and Janusz Górecki. 2005. Pielgrzymki chasydów do grobów cadyków we współczesnej Polsce. Peregrinus Cracoviensis 16: 235-50.

Grażyna od Wszechpośrednictwa, Gizela od Niepokalanego Serca Maryi, and Romana Szymczak, eds. 1999. Z dawna Polski Tyś Królowa. Przewodnik po sanktuariach maryjnych. Koronowane wizerunki Matki Bożej 1717-1999. Szymanów: Siostry Niepokalanki. 
Jabłoński, Zachariasz. 2000. Pielgrzymowanie na Jasną Górę w czasie i przestrzeni. Częstochowa: Wyższa Szkoła Języków Obcych i Ekonomii.

Jackowski, Antoni. 2003. Święta przestrzeń świata. Podstawy geografii religii. Kraków: Wydawnictwo Uniwersytetu Jagiellońskiego.

Jackowski, Antoni. 2005. Jasnogórskie pielgrzymowanie bez granic. Częstochowa: Tygodnik Katolicki "Niedziela".

Jackowski, Antoni, and Izabela Sołjan, eds. 2005. Leksykon Pielgrzymek Jana Pawła II. Kraków: Wydawnictwo WAM.

Jackowski, Antoni, Izabela Sołjan, and Elżbieta Bilska-Wodecka. 1999. Religie świata. Szlaki pielgrzymkowe, Wielka encyklopedia geografii świata, t. 15. Poznań: Wydawnictwo KURPISZ.

Kaszowski, Ludwik. 1996. Chrześcijańskie spojrzenie na środowisko geograficzne jako przestrzeń pielgrzymowania. Peregrinus Cracoviensis 4: 75-91.

Kobus, Zbigniew. 2006. Bilans reform liturgicznej w czterdzieści lat po Soborze Watykańskim II. In Recepcja wskazań Soboru w życiu $i$ działaniu Kościoła w Polsce. Niektóre wyzwania 40 lat po Soborze Watykańskim II (1965-2005), cz. I. Edited by Kazimierz Półtorak. Szczecin: Katedra Teologii Pastoralnej i Liturgiki Wydziału Teologicznego Uniwersytetu Szczecińskiego, pp. 71-87.

Kodeks Prawa Kanonicznego (przekład polski zatwierdzony przez Konferencję Episkopatu). 1984. Poznań: Wydawnictwo Pallottinum.

Konopka, Hanna, and Adrian Konopka. 2003. Leksykon historii Polski po II wojnie światowej 1944-1997. Warszawa: Oficyna Wydawnicza Graf-Punkt.

Kopiczko, Andrzej. 1996. Kościół warmiński a polityka wyznaniowa po II wojnie światowej. Olsztyn: Ośrodek Badań Naukowych.

Krogmann, Alfred. 2007. Religiózny cestovný ruch v Nitrianskom kraji. Nitra: UKF.

Krukowski, Józef. 1987. Recepcja Soboru Watykańskiego II a struktury kościelne w Polsce. In W dwudziestolecie Soboru Watykańskiego II. Recepcja—doświadczenia-perspektywy. Edited by Józef Homerski and Franciszek Szulc. Lublin: Towarzystwo Naukowe Katolickiego Uniwersytetu Lubelskiego, pp. 119-32.

Krzyżak, Lesław. 2014. Pielgrzymki w dokumentach i liturgii Kościoła. Łódzkie Studia Teologiczne 23: 93-106. [CrossRef]

Kukiz, Tadeusz. 2000. Madonny Kresowe i inne obrazy sakralne z Kresów w diecezjach Polski (poza Ślaskiem), t. I.. Warszawa: Stowarzyszenie "Wspólnota Polska".

Kukiz, Tadeusz. 2002. Madonny Kresowe i inne obrazy sakralne z Kresów w diecezjach Polski. Suplement. Warszawa: Stowarzyszenie "Wspólnota Polska".

Kupiszewska, Helena Teresa. 2014. Królowa Polski o wielu obliczach. Wizerunki Matki Bożej koronowana przez Prymasa Tysiąlecia Stefana Kardynała Wyszyńskiego. Częstochowa: Fundacja "Czas to Miłość".

Leszczyńska, Cecylia. 2018. Polska 1918-2018. Historia Polski w liczbach. Tom 5. Warszawa: Zakład Wydawnictw Statystycznych.

Maddrell, Avril, Veronica Della Dora, Alessandro Scafi, and Heather Walton. 2014. Christian Pilgrimage, Landscape, and Heritage: Journeying to the Sacred. London: Routledge.

Margry, Jan Peter, ed. 2008. Shrines and Pilgrimage in the Modern World: New Itineraries into the Sacred. Amsterdam: University of Amsterdam Press.

Mariański, Janusz. 1987. Apostolstwo świeckich w Kościele. In W dwudziestolecie Soboru Watykańskiego II. Recepcja—doświadczeniaperspektywy. Edited by Józef Homerski and Franciszek Szulc. Lublin: Towarzystwo Naukowe Katolickiego Uniwersytetu Lubelskiego, pp. 95-117.

Mróz, Franciszek, and Łukasz Mróz. 2012. Koronacje papieskie (na mocy dekretu Stolicy Apostolskiej) wizerunków Najświętszej Maryi Panny w Polsce w latach 1990-2011. Peregrinus Cracoviensis 23: 31-50.

Mróz, Franciszek, and Łukasz Mróz. 2015. Pielgrzymowanie do sanktuarium Matki Bożej Starowiejskiej w Starej Wsi-przeszłość i teraźniejszość. In Kreowanie przedsiębiorczości w turystyce na terenach wiejskich oraz ochrona środowiska i dziedzictwa kulturowego. Edited by Jan Krupa. Dynów: Związek Gmin Turystycznych Pogórza Dynowskiego, pp. 295-310.

Mróz, Franciszek. 2000. Sanktuaria i kaplice Bożego Grobu w Polsce. Peregrinus Cracoviensis 8: 79-114.

Mróz, Franciszek. 2008. Geneza i funkcjonowanie sanktuariów Bożego Miłosierdzia w Polsce. Peregrinus Cracoviensis 19: 47-72.

Mróz, Franciszek. 2013. Sanktuaria Pańskie powstałe w Polsce po zakończeniu II wojny światowej. Geneza i funkcjonowanie. In Non cesso gratias agere Deo et hominibus. Prace ofiarowane Ojcu dr. Anzelmowi Januszowi Szteinke OFM z okazji Złotego Jubileuszu Kaptaństwa i ponad 50-letniej pracy historyczno-pisarskiej. Edited by Wacław Michalczyk and Celestyn Paczkowski. Warszawa: Drukarnia Styl, pp. 259-85.

Mróz, Franciszek. 2014. Pielgrzymki i turystyka religijna w Polsce po transformacji ustrojowej 1989 r. Geografické Informácie $18: 124-37$. [CrossRef]

Mróz, Franciszek. 2018. Szlak Maryjny—Światło ze Wschodu. Kraków: Instytut Dialogu Międzykulturowego im, Jana Pawła II w Krakowie.

Mróz, Franciszek. 2019. Changes in religious tourism in Poland at the beginning of the 21st century. Turyzm 29: 95-103. [CrossRef]

Mróz, Franciszek. 2021a. Geneza i typologia sanktuariów Pańskich w Polsce. Kraków: Wydawnictwo Naukowe Uniwersytetu Pedagogicznego w Krakowie.

Mróz, Franciszek. 2021b. The Impact of COVID-19 on Pilgrimages and Religious Tourism in Europe During the First Six Months of the Pandemic. Journal of Religion and Health 60: 625-45. [CrossRef]

Myszor, Jerzy. 2008. Pielgrzymkowy PRL. Gość Niedzielny 2008: 2.

Ogórek, Zenon. 2006. Recepcja odnowy liturgicznej Soboru Watykańskiego II w Diecezji Warmińskiej. Olsztyn: Zakład Poligraficzny "Gutgraf".

Okońska, Maria. 2001a. Stuga Boży Stefan Kardynał Wyszyński. Warszawa: Oficyna Wydawniczo-Poligraficzna "ADAM". 
Okońska, Maria. 2001b. Wszystko postawit na Maryję. Warszawa: Oficyna Wydawniczo-Poligraficzna "ADAM".

Okońska, Maria. 2008. Świadectwo. Studia Prymasowskie UKSW 2: 114-24.

Ostrowski, Maciej. 2017. Sakralny krajobraz—środowisko pielgrzymowania. In Dziedzictwo religijne i kulturowe Drogi św. Jakuba-w 30. rocznicę uznania szlaku za pierwszy Europejski Szlak Kulturowy. Edited by Piotr Roszak, Franciszek Mróz and Łukasz Mróz. Kraków: Wydawnictwo "Czuwajmy", pp. 27-33.

Ostrowski, Maciej. 2020. Duszpasterstwo w świecie turystyki. Kraków: Wydawnictwo Naukowe Uniwersytetu Papieskiego Jana Pawła II. Oviedo, Lluis. 2019. Meaning and Religion: Exploring Mutual Implications. Scientia et Fides 1: 25-46. [CrossRef]

Półtorak, Kazimierz. 2006. Wprowadzenie. In Recepcja wskazań Soboru w życiu i działaniu Kościoła w Polsce. Niektóre wyzwania 40 lat po Soborze Watykańskim II (1965-2005), cz. I. Edited by Kazimierz Półtorak. Szczecin: Katedra Teologii Pastoralnej i Liturgiki Wydziału Teologicznego Uniwersytetu Szczecińskiego, pp. 5-6.

Przygoda, Wiesław. 2006. Recepcja wskazań Soboru watykańskiego II w posłudze charytatywnej Kościoła w Polsce. In Recepcja wskazań Soboru w życiu i działaniu Kościoła w Polsce. Niektóre wyzwania 40 lat po Soborze Watykańskim II (1965-2005), cz. I. Edited by Kazimierz Półtorak. Szczecin: Katedra Teologii Pastoralnej i Liturgiki Wydziału Teologicznego Uniwersytetu Szczecińskiego, pp. 91-118.

Reader, Ian. 2007. Pilgrimage growth in the modern world: Meanings and implications. Religion 37: 210-29. [CrossRef]

Robinson, Martin. 1997. Sacred Places. Piligrims Paths. London: HarperCollins.

Roszak, Piotr. 2017. Pilgrimage as sacramentum peregrinationis? Discovering the Ecclesiological Background of the Camino de Santiago. In The Way of St. James: Renewing Insights. Edited by Enrique Alarcon and P. Roszak. Pamplona: Eunsa, pp. $137-57$.

Roszak, Piotr. 2020. Mute Sacrum. Faiths and its Relation to Heritage on the Camino de Santiago. Religions 11: 70. [CrossRef]

Roszak, Piotr, and Sławomir Tykarski. 2020. Popular piety and devotion to parish patrons in Poland and Spain, 1948-98. Religions 11: 658. [CrossRef]

Singh, Sagar. 2004. Religion, Heritage and Travel: Case References from the Indian Himalayas. Current Issues in Tourism 7: 44-65. [CrossRef]

Skowron-Charif, Barbara. 2001. Losy wizerunków maryjnych z terenów wschodnich Drugiej Rzeczypospolitej. Peregrinus Cracoviensis 12: 189-98.

Socha, Piotr. 2000. Rozwój kultu Miłosierdzia Bożego w Polsce i na świecie. Peregrinus Cracoviensis 9: 111-14.

Sołjan, Izabela. 2002. Ośrodki kultu maryjnego w Karpatach Polskich (1772-1992). Kraków: Instytut Geografii i Gospodarki Przestrzennej UJ.

Stala, Józef. 2006. Katecheza rodzinna w świetle posoborowego nauczania Kościoła. In Recepcja wskazań Soboru w życiu i działaniu Kościoła w Polsce. Niektóre wyzwania 40 lat po Soborze Watykańskim II (1965-2005), cz. I. Edited by Kazimierz Półtorak. Szczecin: Katedra Teologii Pastoralnej i Liturgiki Wydziału Teologicznego Uniwersytetu Szczecińskiego, pp. 187-211.

Strzelczyk, Grzegorz. 2008. Recepcja nauczania Soboru Watykańskiego II w Polsce-wybrane aspekty. In Recepcja i wyzwania Soboru Watykańskiego II. Edited by Mariusz Jagielski. Zielona Góra: Wydawnictwo Diecezji Zielonogórsko-Gorzowskiej, pp. $45-57$.

Świeżawski, Stefan. 1987. Vaticanum II a problemy kultury współczesnej. In W dwudziestolecie Soboru Watykańskiego II. Recepcjadoświadczenia—perspektywy. Edited by Józef Homerski and Franciszek Szulc. Lublin: Towarzystwo Naukowe Katolickiego Uniwersytetu Lubelskiego, pp. 59-68.

Timothy, Dallen, and Daniel H. Olsen, eds. 2006. Tourism, Religion and Spiritual Journeys. London and New York: Routledge.

Turner, Victor, and Edith Turner. 1978. Image and Pilgrimage in Christian Culture. New York: Colombia University Press.

Witkowska, Aleksandra. 1996. Uroczyste koronacje wizerunków maryjnych na ziemiach polskich w latach 1717-1992. In Przestrzeń i sacrum. Geografia kultury religijnej w Polsce i jej przemiany w okresie od XVII do XX w. na przykładzie ośrodków kultu i migracji pielgrzymkowych. Edited by Antoni Jackowski, Aleksandra Witkowska, Szczepan Zachariasz Jabłoński, Izabela Sołjan and Elżbieta Bilska. Kraków: Instytut Geografii Uniwersytetu Jagiellońskiego.

Wlaźlak, Władysław Piotr, and Andrzej Sznajder. 2009. Ruch pielgrzymkowy na Jasna Górę 1945-1989. Wybór dokumentów. Katowice: Oddział Instytutu Pamięci Narodowej-Komisji Ścigania Zbrodni przeciwko Narodowi Polskiemu w Katowicach.

Włodarczyk, Tadeusz. 1974. Konkordaty. Zarys historii ze szczególnym uwzględnieniem XX wieku. Warszawa: Wydawnictwo Naukowe PWN.

Wysocki, Jan Wiesław. 2008. Wpływ przemian Października 1956 r. na politykę władz państwowych wobec Kościoła w latach 1956-1966. In Kościót i Prymas Stefan Wyszyński 1956-1966. Edited by Adam Dziurok and Wiesław Jan Wysocki. Katowice and Kraków: Instytut Pamięci Narodowej Komisja Ścigania Zbrodni przeciw Narodowi Polskiemu, Uniwersytet Kardynała Stefana Wyszyńskiego w Warszawie, pp. 15-22.

Wyszyński, Stefan. 2006. Dzieła zebrane. T. 5: 1959. Warszawa: Instytut Papieża Jana Pawła II w Warszawie, Wydawnictwo im. Stefana Kardynała Wyszyńskiego SOLI DEO.

Wyszyński, Stefan. 2009. Dzieła zebrane. T. 8: Styczeń-lipiec 1962. Warszawa: Instytut Papieża Jana Pawła II w Warszawie, Wydawnictwo im. Stefana Kardynała Wyszyńskiego SOLI DEO. First published 1962.

Zaleski, Wincenty. 1988. Sanktuaria Polskie. Katalog encyklopedyczny miejsc szczególnej czci Osób Trójcy Przenajświętszej, Matki Bożej i Świętych Pańskich. Warszawa: Wydawnictwo Salezjańskie.

Żaryn, Jan. 2008. Maryi trudne wędrowanie po Polsce. Gość Niedzielny 2008: 4-5. 
Zieliński, Zygmunt. 2008. Duszpasterski aspekt obchodów Tysiąclecia Chrztu Polski. In Kościót i Prymas Stefan Wyszyński 1956-1966. Edited by Adam Dziurok and Wiesław Jan Wysocki. Katowice and Kraków: Instytut Pamięci Narodowej Komisja Ścigania Zbrodni przeciw Narodowi Polskiemu, Uniwersytet Kardynała Stefana Wyszyńskiego w Warszawie, pp. 77-85.

Ziółkowski, Marek. 1981. Sanktuaria i pielgrzymki. In Kościót katolicki w Polsce 1918-1990. Rocznik statystyczny. Edited by Lucjan Adamczuk and Witold Zdaniewicz. Warszawa: Główny Urząd Statystyczny, pp. 224-25. 